Journal of Product Innovation Management, Volume 35, Issue 2, March 2018, pp. 254-279 DOI:10.1111/jpim.12394

\title{
Harnessing difference: A capability-based framework for stakeholder engagement in environmental innovation
}

\author{
Rosina Watson*, Hugh N. Wilson*, Palie Smart** and Emma K. Macdonald* \\ ${ }^{*}$ Cranfield School of Management, Cranfield University, UK \\ **School of Economics, Finance and Management, University of Bristol, UK
}

Address correspondence to: Hugh N. Wilson, e-mail: hugh.wilson@cranfield.ac.uk

Accepted for Journal of Product Innovation Management, 8 May 2017 


\section{BIOGRAPHICAL SKETCHES}

Rosina Watson is a doctoral researcher at Cranfield School of Management, UK. Her research centres on sustainable innovation, both in large commercial organisations and by entrepreneurs. As research fellow on an EU funded project investigating the role of individual users and entprepreneurs in sustainable transitions (EU-InnovatE), she led research which crowdsourced ideas for sustainable entrepreneurship policy. Before commencing her $\mathrm{PhD}$, she was head of corporate sustainability at Home Retail Group, and has previously held senior financial and commercial roles at Home Retail Group, Carphone Warehouse, ITV and Shell.

Dr. Hugh N. Wilson is a professor of marketing at Cranfield School of Management, UK. He researches sustainable marketing and innovation, and he directs Cranfield's Masters in Management and Corporate Sustainability. He worked for 20 years as a marketer and consultant with IBM, Xerox, NCR and Logica CMG. He has published in Journal of Marketing, Journal of the Academy of Marketing Science, Journal of Retailing and British Journal of Management among other journals. He also writes extensively for practitioners in Harvard Business Review and elsewhere.

Dr Palie Smart is a professor in innovation and operations management at Bristol University, UK. Her research focuses on new models of innovation for sustainable business, in partnership with Cambridge University and the UK Engineering and Physical Sciences Research Council. She has published in Research Policy, British Journal of Management, International Journal of Operations and Production Management, International Journal of Management Reviews, R\&D Management and International Journal of Production Economics. She is a member of the UK Innovation Caucus, a new research policy body developed to support sustainable innovation-led economic growth in the UK.

Dr. Emma K. Macdonald is a professor of marketing at Cranfield School of Management, UK. She is adjunct at the Ehrenberg-Bass Institute for Marketing Science at the University of South Australia. She researches customer experience and value co-creation and directs the Cranfield Customer Management Forum. Prior to joining the academic world she worked in telecommunications marketing and market research. She has published in Journal of Marketing, Journal of Retailing, Journal of Business Research, and Technology Forecasting \& Social Change among other journals. She also writes for practitioners in Harvard Business Review and elsewhere. 


\begin{abstract}
Innovation for environmental sustainability requires firms to engage with external stakeholders to access expertise, solve complex problems, and gain social legitimacy. In this open innovation context, stakeholder engagement is construed as a dynamic capability that can harness differences between external stakeholders to augment their respective resource bases. An integrative systematic review of evidence from 88 scientific articles finds that engaging stakeholders in environmental innovation requires three distinct levels of capability: specific operational capabilities; first-order dynamic capabilities to manage the engagement (engagement management capabilities); and second-order dynamic capabilities to make use of contrasting ways of seeing the world to reframe problems, combine competencies in new ways, and co-create innovative solutions (value framing), and to learn from its stakeholder engagement activities (systematized learning). These findings enhance understanding of how firms can effectively incorporate stakeholder perspectives for environmental innovation, and provide an organizing framework for further research into open innovation and co-creation more broadly. Wider contributions to the dynamic capabilities literature are to i) offer a departure point for further research into the relationship between first-order and second-order dynamic capabilities, ii) suggest that institutional theory can help explain the dynamic capability of value framing, iii) build on evidence that inter-institutional learning is contingent on not only the similarity but also the differences between organizational value frames, and iv) suggest that operating capabilities impact on the effectiveness of dynamic capabilities, rather than only the other way around, as is usually assumed. A methodological contribution is made through the application of quality assessment criteria scores and intercoder reliability statistics to the selection of articles included in the systematic review.
\end{abstract}

Keywords: environmental innovation; dynamic capabilities; stakeholder engagement; institutional logics; value frames; systematic literature review 


\section{PRACTITIONER POINTS}

- When engaging with external stakeholders in pursuit of environmental innovation, companies should recognise that competing value frames, or 'ways of seeing the world' represent a challenge but also an opportunity.

- Competing value frames may exist between those leading environmental innovation and their external stakeholders but also between various internal functions.

- As well as developing skills in managing stakeholder engagements, companies need the capabilities which help harness these differences between value frames and use them to reframe problems, combine competencies in new ways, and co-create innovative solutions ('value framing capability').

- Structures and processes can help an organization 'learn to learn' from their stakeholders, provided they support the accumulation and sharing of learning from stakeholder engagement, and facilitate the ongoing evolution in what is known across the organization about how best to engage stakeholders ('systematized learning capability').

- These two capabilities are linked since a value framing capability helps organizations question the assumptions of the problems at hand, and therefore be more receptive to learning opportunities from engagement with external stakeholders.

- These capabilities may have broader application to innovation that involves engagement with external stakeholders, such as open innovation in non-environmental contexts. 


\section{INTRODUCTION}

Innovation for environmental sustainability (hereafter "environmental innovation") represents the subset of sustainability-oriented innovation (Adams et al., 2016; Klewitz and Hansen, 2014) addressing the environmental dimension of sustainability. It is defined as "the production, assimilation or exploitation of a product, production process, service or management or business method that is novel to the organisation (developing or adopting it) and which results, throughout its life cycle, in a reduction of environmental risk, pollution and other negative impacts of resources use (including energy use) compared to relevant alternatives" (Kemp and Pearson, 2008, p.7). Environmental innovation is critically important in practice. This is because resource scarcity evidenced by commodity prices which increased by nearly $150 \%$ from 2002 to 2010 , erasing a century's worth of real price declines (World Economic Forum, 2014) - coupled with stakeholder pressure to address sustainable development have led many organizations to pursue environmental innovation as a way to achieve environmental, social and economic outcomes simultaneously.

Environmental innovation poses complex, systemic challenges for how firms engage external stakeholders such as customers, suppliers, government, civil society and NGOs. First, this type of innovation is prevalent in rapidly changing business and natural environment contexts, demanding continual resource reconfiguration (Hart, 1995). This may represent a technological frontier for the firm which due to their inexperience may require external support (De Marchi and Grandinetti, 2013). Second, it often requires engagement with multiple stakeholders who are very different from each other in terms of their institutional origins and logics and the ways they assess and value success and failure (Driessen and Hillebrand, 2013; Polonsky and Ottman, 1998). Third, it may demand innovation which moves beyond product and process innovation to business model innovation, and as such involves expertise sourced through external and unfamiliar collaboration (Albino, Dangelico and Pontrandolfo, 2012; De Marchi and Grandinetti, 2013).

Building on research identifying stakeholder engagement as an organizational capability (Ayuso et al., 2011; Hart, 1997; Hart and Sharma, 2004; Sharma and Vrendenburg, 1998), stakeholder 
engagement for innovation is construed as a dynamic capability - defined as "the firm's ability to integrate, build, and reconfigure internal and external competences to address rapidly changing environments" (Teece et al., 2007, p.516). This is because relationships with external stakeholders give firms access to resources outside their boundaries, and augment the organizational resource base (Helfat et al., 2007), and because stakeholder relationships driven by a need for innovation are more strongly geared toward resource reconfiguration than other types of alliances (Schilke, 2014). Stakeholder engagement has commonly been understood by stakeholder theorists as a transactional process whereby managers learn what is important to their various stakeholder groups, process this information internally, and try to reconcile the stakeholders' divergent, incompatible interests (Donaldson and Preston, 1995; Hill and Jones, 1992). Recent stakeholder engagement literature, however, has moved away from the idea of making trade-offs between interests, towards exploring the complementarity between stakeholders' resource allocations (Henisz et al., 2014) and the synergistic links between the demands of business and society (O'Riordan and Fairbrass, 2014). There is growing recognition that engaging with stakeholders can "deliver innovative solutions that benefit a particular stakeholder group while increasing the pie for all stakeholders" (Eccles, Ioannou and Serafeim, 2014, p.2848), but also that harnessing stakeholder diversity to drive innovation requires approaches which attempt to "structure and utilize discord rather than to reduce or eliminate it” (Dawkins, 2015, p.1).

Open innovation research has recently explored how firms can leverage stakeholder insight to their advantage (West et al., 2014). Collaborating with customers and other stakeholders is increasingly seen in the open innovation (Chesbrough, 2012; von Hippel, 2005; West et al., 2014) and co-creation literature (Nonaka, 1991; Payne et al., 2008) as a way to improve idea generation and concept development, resulting in products more highly valued by customers (Roberts and Candi, 2014). In addition to product and service innovation, innovation research has widened in scope to incorporate process and business model innovation (Johnson and Christensen, 2008) and now considers more diverse innovation partners including customers, suppliers or sector experts, 
such as universities (West and Bogers, 2014). Despite this growing academic interest, there is surprisingly limited research on engagement by public, private and charitable sector stakeholders where different institutional settings lead to inherently different values and logics (Holmes and Smart, 2009) and for which environmental innovation offers an exemplary context.

Accordingly, this article addresses the question of how firms engage with their stakeholders, from distinct institutional settings, to enable environmental innovation through a systematic review of 88 scientific articles representing the partial and fragmented literature on stakeholder engagement for environmental innovation. Recent reviews of the sustainability-oriented innovation literature agree that this innovation depends on stakeholder collaboration activities (Adams et al., 2016), and that interaction with external actors can increase the organization's innovative capability (Klewitz and Hansen, 2014). This research builds on these reviews by narrowing the focus specifically on stakeholder engagement as an organizational capability. A methodological contribution is also made through the application of quality assessment criteria scores (Pittaway et al., 2004) and intercoder reliability statistics (Macdonald, Kleinaltenkamp and Wilson, 2016) to the selection of articles included in the review.

Taking an existing resource-based model for integrating stakeholders into new product development (Verona, 1999) as a starting point, a process of analytic induction (Bansal and Roth, 2000) was used to evolve a revised framework in light of the reviewed literature, informed by the broader literature on dynamic capabilities, organizational learning, absorptive capacity and institutional logics. A hierarchical capability-based framework describing the organizational capabilities required to engage stakeholders effectively in environmental innovation is thereby developed (shown at Figure 1).

The findings show that engaging with stakeholders to drive environmental innovation requires three levels of capabilities. It requires specific operational capabilities; complex first-order dynamic capabilities to manage the engagement (engagement management capabilities); and second-order dynamic capabilities (engagement learning capabilities) to allow organizations to co-create value 
(value framing) and to learn from their engagement (systematized learning). This article thereby enhances understanding of how firms can effectively incorporate stakeholder perspectives for environmental innovation and provides an organizing framework for further research in this subfield of cross-sector innovation studies. Value framing enables organizations to navigate and harness the differences in the ways of seeing the world that exist between them and their stakeholder groups. Instead of seeing these differences as unassailable conflict or as opposing positions which have to be negotiated to a compromise, managers in the innovating firm think about the complete system operating beyond the immediate boundaries of the innovation context. They empathize with the alternative value frames of their collaborators, and harness these differences by using them to rethink (or reframe) the problem, combine competencies in new ways, and co-create innovative solutions. Systematized learning allows organizations to learn from specific individuals working with stakeholders on discrete innovation projects, because they can share that learning across the organization, and reconfigure their human and capital resources accordingly, so that the organization is 'learning to learn' and continually developing its stakeholder engagement capabilities. It is suggested that organizations with a value framing capability also have the potential to achieve this 'higher order' learning (Quist and Tukker, 2013) because they are able to question the boundary conditions, frames or assumptions of the problems at hand.

This research therefore contributes to the burgeoning literature on innovation for environmental sustainability. Through synthesis of the current literature, a hierarchical capability framework is developed which forms a basis for future empirical research of this phenomenon. A contribution is also made to the literature on innovation models and processes which integrate the insights and perspectives of external stakeholders, such as open innovation and co-creation. Open innovation research focuses on how innovation is sourced from external agents, but has largely overlooked how this insight is integrated into businesses (West and Bogers, 2014). The capabilities framework that emerges from this review sheds light on how organizations engage their stakeholders in 
environmental innovation at least, and may also provide a basis for an understanding of stakeholder engagement in other open innovation contexts.

Finally, wider contributions of this work to the literature on dynamic capabilities are to: i) offer a starting point for further empirical research into the relationship between first-order and secondorder dynamic capabilities, building on Schilke's (2014) work on strategic alliances, ii) respond to the call for research to look at institutional theory to increase understanding of how dynamic capabilities develop (Schilke, 2014) by identifying value framing as a second-order capability, iii) build on the notion (Lane and Lubatkin, 1998) that inter-organizational learning is dependent (inter alia) on the similarity, or difference of the value frames (or dominant logics) of the organizations through evidencing a link between value framing and systematized learning, and iv) offer evidence of operating capabilities having an impact on the effectiveness of dynamic capabilities, "in contrast to the current unidirectional emphasis in the literature on how dynamic capabilities affect operating capabilities" (Newey and Zahra, 2009, p.S82). This research offers some insight into how the three levels of capabilities co-exist and work together with potential wider implications for the capabilities literature.

The next section details the systematic review method. The hierarchical capabilities-based framework is then introduced, and used to structure a synthesis of the literature. Finally, findings are discused, along with their implications for managers and innovation teams, and future research directions are proposed.

\section{METHOD}

A comprehensive synthesis of academic literature on stakeholder engagement in environmental innovation was conducted using Tranfield et al.'s (2003) systematic review approach. Inspired by systematic reviews in the field of medicine, this approach allows other researchers to replicate and update the literature review by providing a transparent account of the reviewer's procedures. This review proceeded through searching, screening, and extraction/synthesis stages as follows. 
Searching. Relevant studies were searched for in the scientific literature represented by peerreviewed journals. An initial scoping of the literature, including previous related reviews, identified the keywords to use when constructing search strings (detailed in Table 1). Two leading electronic databases, EBSCO and ABI/INFORM, were searched for articles whose titles and/or abstracts contained at least one of the search terms from all four themes, by linking the strings in Table 1 with the Boolean operator (AND). In this way, articles addressing the concept of environmental innovation in conjunction with that of stakeholder engagement were identified. This search across both databases returned a total of 1,079 titles.

\section{TABLE 1}

Screening. An initial screening of article titles and abstracts, informed by the inclusion and exclusion criteria in Table 2, led to the retention of 97 articles relevant to the research question. 15 additional articles were sourced from the authors' prior reading, cross-referencing and snowballing from database-sourced articles. These 112 full articles were scored independently by three authors against the quality assessment shown at Appendix 1 (Pittaway et al., 2004), with the 88 articles achieving a total score of eight (out of a possible 15) or above by the majority of the authors being retained in the review. Following Macdonald, Kleinaltenkamp and Wilson (2016), intercoder reliability was checked with the proportional reduction in loss method (Rust and Cooil, 1994) and found to be at a very satisfactory level of $95 \%$.

\section{TABLE 2}

Extraction and synthesis. Information from these 88 articles was summarized in an Excel spreadsheet organized under descriptive, methodological and thematic categories. The dataset from the selected articles was heterogeneous, from multiple contexts and contained a mix of empirical (qualitative and quantitative) and conceptual articles. An integrative and qualitative cross-case analysis approach to synthesis was therefore used, each article being equivalent to a case (Mays et al., 2005). Using an existing product development model as a starting-point (Verona, 1999) an analytic induction approach was adopted (Bansal and Roth, 2000; Wilson, 2004) whereby we 
considered 'cases' (here, articles) one by one to look for evidence which supported, amended or contradicted this prior theory, and iteratively modified the framework as needed to fit each new round of data. Moving between this evolving framework, the review articles, and the broader literature on dynamic capabilities, organizational learning, absorptive capacity and institutional logics, a conceptual framework of the organizational capabilities required to engage stakeholders in environmental innovation was developed, including an elaboration of the underlying dimensions of these capabilities. This analysis can be characterized as integrative (Dixon-Woods et al., 2004; Rousseau et al., 2008) since it both reviews the literature but also organizes it in a conceptually new way. The process for naming and defining constructs follows Gioia, Corley and Hamilton (2012) whereby literature is examined to establish where an existing term accurately represents the data, and where it does not, a new term is defined from the data. The final framework is shown in Figure 1, with each element of the framework described and evidenced more fully in Results: A hierarchical capability-based framework.

\section{RESULTS: DESCRIPTIVE ANALYSIS}

Journals and rankings. In line with recent reviews of sustainability-oriented innovation literature (Adams et al., 2016; Klewitz and Hansen, 2014), the reviewed articles are situated within multiple disciplines, and distributed widely across journals. Consistent with an immature body of literature, the 88 articles come from 41 journals, 28 of which provide one article each. Journal of Cleaner Production and Business Strategy and the Environment together published almost a third of the studies, with 45 articles overall in environmental or ethical journals. There are additional clusters in innovation/R\&D-related (20) and marketing-related (7) journals. Research interest is increasing, with 56 articles published in 2010 or later.

\section{TABLE 3}

Type of innovation. Klewitz \& Hansen (2014) identify three types of sustainability-oriented innovation: product innovation, involving improved or new products/services; process innovation relating to the production of goods and services that increase eco-efficiency; and, organizational 
innovation dealing with "people and the organization of work" (OECD, 2005, p.55). Based on this classification, 26 studies address product innovation, 25 organizational innovation, 19 consider process innovation, or a combination of product and process innovation and the remaining 18 address environmental innovation generally, or do not specify an innovation type.

Type of research. The majority of empirical studies are qualitative (46), ranging from single case studies to 47 cases. Quantitative studies (22) tend to be based on secondary innovation surveys such as the EU Community Innovation Survey, but also use questionnaires. Very few studies are longitudinal, even though analysing the effects of stakeholder engagement on innovation might be better studied in this way (see Le Ber \& Branzei, 2010a; Horbach, 2008 for exceptions). Eight studies use mixed methods and the remaining 12 are conceptual.

Type of stakeholder. 60 articles deal primarily with external stakeholder engagement. Many of these address external stakeholders generally, with users/consumers, suppliers and NGOs most frequently researched as single stakeholder groups (Table 4). 28 consider engagement with internal stakeholders, typically looking at collaboration between functional teams or departments.

\section{TABLE 4}

\section{RESULTS: A HIERARCHICAL CAPABILITY-BASED FRAMEWORK}

Prior research has established a three-part hierarchical structure to organizational capabilities (Ambrosini and Bowman, 2009; Collis, 1994; Danneels, 2002; Winter, 2003; Zahra et al., 2006). Operational ${ }^{\mathrm{i}}$ capabilities are those that enable a firm to "make a living" in an equilibrium state. To adjust this equilibrium state in response to environmental changes, firms rely on first-order dynamic capabilities (Collis, 1994; Winter, 2003); these are the routines which reconfigure the organizational resource base (Schilke, 2014). Second-order capabilities operate on these first-order dynamic capabilities (Collis, 1994; Winter, 2003); these routines in turn reconfigure first-order capabilities. Second-order capabilities can be thought of as 'learning-to-learn' capabilities (Collis, 1994), doubleloop learning (Argyris and Schön, 1978) or regenerative dynamic capabilities (Ambrosini and Bowman, 2009) and comprise activities such as analysing what aspects of first-order dynamic 
capabilities work or do not work, codifying past experience and transferring knowledge within the organisation. These activities are similar to the elements of Nonaka's (1991) knowledge spiral in which organizational knowledge is embedded and institutionalized within the organization, whilst also continually developing. As Zollo and Winter, (2002, p.340) explain: "Dynamic capabilities arise from learning; they constitute the firm's systematic methods for modifying operating routines. To the extent that the learning mechanisms are themselves systematic, they could be regarded as 'second-order' dynamic capabilities."

Verona (1999) developed a model which articulated the impact of the first two levels of organizational capability on the efficiency and effectiveness of new product development. At the operational level, he included technological and marketing capabilities. At the first-order level, he identified "external integrative capabilities" which absorb critical knowledge and resources from external sources and "internal integrative capabilities" which blend the technical capabilities developed in the operational areas. By refining and updating this model in the context of environmental innovation, based on the evidence from a comprehensive literature review, this article presents an enhanced framework which refines understanding of the capabilities needed to engage stakeholders in environmental innovation on these first two tiers, but also provides evidence that an additional third tier of second-order dynamics capabilities is involved.

At the operational level, stakeholder engagement in environmental innovation requires a specific environmental capability alongside technological and marketing capabilities. Next, it demands complex first-order dynamic capabilities (comprising processes, structure and routines) to manage engagement with both external and internal stakeholders - which are conceptualized as engagement management capabilities. Following Verona (1999), these are termed "external integrative" capabilities if they relate to the direct relationship with external stakeholders, and "internal integrative" if they relate to the sharing and use of the acquired information across groups of internal stakeholders. The processes and routines described in this tier of the framework can be thought of as those underlying a firm's absorptive capacity (the ability to acquire, assimilate, 
transform and exploit knowledge), which has more recently been conceptualized as a dynamic capability (Zahra and George, 2002). The absorptive capacity literature (Cohen and Levinthal, 1990) primarily uses R\&D spending as a "coarse grained absolute measure of absorptive capacity" (Lane and Lubatkin, 1998, p.473) whereas the dynamic capability perspective enables elaboration of the broader competencies and culture an organization requires to integrate innovation from external sources (West and Bogers, 2014).

Accordingly, evidence is found of a further tier of second-order dynamic capabilities which allow organizations to continuously learn from, modify and improve their first-order stakeholder engagement activities. Alliance learning routines have previously been conceptualized as secondorder dynamic capabilities (Kale and Singh, 2007; Schilke, 2014; Zollo and Winter, 2002); in the context of this research, these capabilities are conceptualized as engagement learning capabilities. The review evidence suggests that organizations not only need to manage their stakeholder engagements to understand the 'know-what' and 'know-how' of environmental innovation, but also to learn at an institutional level from that engagement. This is both to enable them to improve their first-order stakeholder management capabilities, but also to allow them to maximise their potential for future inter-organizational learning by recognizing and valuing new external knowledge through the refinement of the organization's concept of its own purpose - the 'know-why' portion of its knowledge (Lane and Lubatkin, 1998) - a process we term value framing (after Le Ber and Branzei, 2010). The next section details each of the elements comprising this three-tier hierarchical framework (Figure 1) starting with first-order, then second-order and finishing with operational capabilities.

\section{FIGURE 1}

\section{Engagement management capabilities (First-order dynamic capabilities)}

Research suggests that the environmental innovation process requires greater engagement with external stakeholders than traditional innovation (Albino et al., 2012; Horbach, 2008; Klewitz and Hansen, 2014; De Marchi, 2012; De Marchi and Grandinetti, 2013; Petruzzelli et al., 2011). Sharma 
and Vrendenburg (1998) found evidence in firms with proactive environmental strategies of the development of a capability for stakeholder integration. Moreover, this external stakeholder engagement must be combined with internal stakeholder collaboration to achieve environmental innovation (Ayuso et al., 2006, 2011; van Bommel, 2011; Driessen and Hillebrand, 2013; Lenox and Ehrenfeld, 1997; de Medeiros et al., 2014; Petruzzelli et al., 2011). Taking Verona's (1999) conceptualization of external and internal integrative capabilities as a starting point (i.e. firms absorb knowledge through the use of external integrative capability; internal integrative capability then organizes its use), the dimensions which make up these engagement management capabilities, and the supporting evidence from the reviewed literature for each dimension are shown in Tables 5 and 6, and discussed below.

External integrative. 62 (of 88) articles dealt primarily with external stakeholders. Table 5 summarizes key insights from these articles relating to three dimensions which were found to comprise external integrative capability: building bridges, developing engagement processes, and achieving alignment.

Building bridges. The reviewed articles evidence firms using third-party organizations to act as intermediaries with stakeholder groups (Klewitz et al., 2012; Murphy and Arenas, 2011). This "enables organizations to monitor, sense and interact with environmental forces, and to transfer information across boundaries" (Hoffmann, 2007, p.329). For example, Stafford et al. (2000) provide a detailed account of Greenpeace's role as a "strategic bridge" between a manufacturer of household appliances and its stakeholders to enable the development of a more environmentallyfriendly refrigerator. Firms also make use of networks to perform this bridging function. These can be internal to the firm, such as expert panels and stakeholder advisory boards (Hansen and GrosseDunker, 2009), or external to the firm, involving knowledge institutions (Triguero et al., 2013), supply-chain partners (Roy and Whelan, 1992) and governments (Holweg, 2014; von Malmborg, 2007). A few studies recognize the importance of the individuals who play this bridge-building or boundary-spanning role (Hoffmann, 2007; Holmes and Smart, 2009; Murphy and Arenas, 2011). 
Developing engagement processes. The evidence showed firms developing processes and methods to engage with stakeholders in a way that encourages ongoing cooperation and trust. Key success factors for these include regular interaction, direct and open communication, nonhierarchical dialogue, allowing diverse points of view to be explored, empowerment, trust, and transparency (Heiskanen and Lovio, 2010; Hoffmann, 2007; Jamali et al., 2011; Mathur et al., 2008; McDonald and Young, 2012; Spena and De Chiara, 2012). Users in particular need to be better incorporated into design processes by being involved earlier and more frequently (Liao et al., 2013). Achieving alignment. Aligning the goals of cross-functional and inter-organizational project teams through mechanisms such as creating a shared vision, identification of multiple overlapping benefits, sharing experiences, using cooperative information systems and involving the right individuals were also found to be critical for external integration (van Bommel, 2011; Lee and Kim, 2011; Murphy and Arenas, 2011; Senge et al., 2007; Verghese and Lewis, 2007).

\section{TABLE 5}

Internal integrative. Fewer articles (31 of 88) in the review deal primarily with internal stakeholders. Table 6 summarizes key insights from the review articles relating to the three dimensions which were found to comprise internal integrative capability: engaging employees, using environmental data and integrating sustainability.

Engaging employees. Employee engagement in environmental innovation can be influenced by the composition of teams (Bocken et al., 2014), and how business units and reporting lines are set up (Kiron, 2012; Kiron et al., 2013; Kruschwitz and Pflueger, 2012) as well as by the level of support provided by leaders and senior management (Bos-Brouwers, 2010; Kiron, 2012). The time and support employees receive to elaborate on innovative ideas also affects environmental innovation (Bos-Brouwers, 2010).

Using environmental data. Gathering and sharing environmental information using tools such as web-based software platforms, databases, design aids and environmental management systems (EMS) helps firms identify innovations and facilitate the internal collaboration required to 
implement them (Gmelin and Seuring, 2014; Hallstedt et al., 2010; Horbach, 2008; de Kraker et al., 2013; Lenox and Ehrenfeld, 1997). However, management teams should be aware that EMS can steer organizations towards the exploitation of present production systems rather than discontinuous innovations (Könnölä and Unruh, 2007).

Integrating sustainability. Environmental innovation requires collaboration between functions such as marketing, R\&D/innovation, operations, and sustainability/corporate responsibility (Carrillo-Hermosilla et al., 2010; Chang and Lin, 2014; Dangelico and Pujari, 2010; Driessen and Hillebrand, 2013; de Medeiros et al., 2014; Pujari, 2006; Pujari et al., 2003, 2004). This can be achieved by integrating environmental criteria into processes such as strategy development, product development, marketing, and performance management across functions. Specific examples include integrating environmental impact analysis within marketing practices such as market research (Pujari et al., 2004) and including green issues in new product development procedures (Driessen and Hillebrand, 2013).

\section{TABLE 6}

\section{Engagement learning capabilities (Second-order dynamic capabilities)}

The routines used to learn from alliances between commercial organizations have been conceptualized as second-order dynamic capabilities (Kale and Singh, 2007; Schilke, 2014; Zollo and Winter, 2002). These learning routines enable external stakeholder engagement techniques and internal collaboration mechanisms to develop into an organizational capability by incorporating them into the culture and processes of the organization (Driessen and Hillebrand, 2013). They enable organizations to use knowledge and experience gained from individuals or discrete innovation projects to change future action and reconfigure resources at the organizational level. This involves transferring individual and tacit knowledge into explicit organizational knowledge that can be shared among many individuals (Crossan et al., 1999; Nonaka, 1991)

Moreover, the literature suggests that dynamic capabilities consist not only of the organizational processes directed towards innovation and learning, but also the decision frames and heuristics that 
inform a firms' investment choices over time (Helfat et al., 2007). The organizational learning literature suggests that "the way an organization acquires, distributes, interprets and stores market information is tied fundamentally to the 'shared cognitions' that constitute its memory" (Sinkula, 1994, p.43) or its 'collective mind-set' (Crossan et al., 1999). These differences, however, can provide opportunity for innovation: "the confusion created by the inevitable discrepancies in meaning that occur in any organization might seem like a problem. In fact, it can be a rich source of new knowledge - if a company knows how to manage it" (Nonaka, 1991, p.167). It has also been argued that inter-organizational learning is greater when organizations demonstrate similar 'dominant logics' (Lane and Lubatkin, 1998). The institutional logics literature therefore offers insights into how organizations engaging with internal and external stakeholders demonstrating divergent logics can harness the potential for learning from each other.

Institutional logics (Friedland and Alford, 1991) or 'value frames' (Le Ber and Branzei, 2010) provide social groups with values, organizing frameworks and legitimate practices to guide their behaviour in a social context (Meyer and Hammerschmid, 2006). Multiple institutional logics may impose different and potentially conflicting demands on organizations (Oliver, 1991), and researchers have looked at how hybrid organizations deal internally with institutional pluralism (Battilana and Dorado, 2010; Reay and Hinings, 2009) and strive to combine logics to generate innovative solutions to complex problems (Jay, 2013). Reay and Hinings (2009) identify four mechanisms for managing the rivalry of competing logics - all of which allow the logics to co-exist by facilitating and strengthening the identities of separate actors, but also developing collaborative relationships between them.

Although those making the 'business case' for corporate social responsibility (CSR) (Porter and Kramer, 2006, 2011) suggest that aspects of CSR, such as environmental sustainability, are complementary with the traditional commercially-driven business models, many actors still perceive CSR as a trade-off with mainstream business objectives and activities (Barnett, 2007). So, by introducing environmental criteria into the innovation process, inconsistencies may occur between 
the value frames of social groupings with a commercial or a customer-centric value frame and those whose value frames are more oriented to social or environmental outcomes.

The next section presents evidence from the systematic review for how organizations can manage differences between their value frames and those of their external stakeholders, and between groups of internal stakeholders (value framing) in order to harness the potential value creation derived from engaging with them. It also illustrates how they can systematically learn from these value framing processes, through establishing new routines, processes and structures at the organizational level (systematized learning). These two second-order engagement learning capabilities are bidirectionally linked since values and culture influence organizational structures and systems, which can in turn influence organizational values and culture (Ayuso et al., 2006).

Value framing. The reviewed literature reports differences in value frames between firms and their external stakeholders (Le Ber and Branzei, 2010; Holmes and Smart, 2009; Holweg, 2014) as well as between departments within the firm (Aschehoug et al., 2012; Delmas and Toffel, 2004; Guiltinan, 2009; Lenox and Ehrenfeld, 1997). The broad picture that emerges is that organizations need to proactively navigate these competing value frames. Table 7 summarises key insights from these articles relating to the three dimensions which comprise this value framing capability: thinking systemically, empathizing, and hybridizing.

Thinking systemically. First, an organization should consider the interests of all the stakeholders involved in the complete system of relevance to the potential innovation, both within the organization and beyond its boundaries (Senge et al., 2007). Internally, differences in value frames between departments can hinder or limit the scope of environmental innovation (Lenox and Ehrenfeld, 1997; Pujari et al., 2003), for example, more sustainable design practices are "likely to be somewhat constrained by corporate and marketing realities and perceptions" (Guiltinan, 2009, p.20). This requires an organization to set a purpose for environmental innovation that is greater than the individual agendas of its internal functions. Externally, thinking systemically means "focusing on issues that are larger than individual organizations and improving the related systems 
that can benefit all" (Senge et al., 2007, p.52). For example, automotive firms may need to shift their attention from individual company needs (such as government-funded subsidies) towards the collective needs faced by all industry players, in order to progress towards a more sustainable future for the industry (Holweg, 2014).

Empathizing. Organizations should also create the time and space to reflect on the differences in value frames between themselves and their stakeholders, independently and in dialogue with those stakeholders. Senge et al. (2007) describe this as "relational work" which involves "moving beyond 'politeness' or win-lose debates into more authentic and reflective interactions characterized by candour, openness and vulnerability" (p.47). This includes listening openly to stakeholders, without applying filters that may be associated with the listener's own value frame. For example, Aschehoug et al. (2012) found that the cultural frame of a department affected the way it responded to environmental information available from external stakeholders, resulting in a substantial gap between the information available and what the firm actually knew. In a similar vein, Hoffmann (2007) reported that the ability of a company to learn from customer involvement in sustainable product development was limited by filtering mechanisms constraining the company to information considered important by the recipient.

Hybridizing. Previous research has considered how hybrid organizations combine different institutional logics (Battilana and Dorado, 2010; Jay, 2013; Reay and Hinings, 2009). This literature has found that commercial organizations striving to incorporate environmental goals into their conventional business models also need to reconcile competing logics through a process of 'hybridizing' the logics of different internal stakeholders (Bondy and Wilson, 2013), and between their internal logics and the logics of the external stakeholders with whom they are engaging. The evidence from the review suggests two stages to this: acknowledging organizational tensions and co-creating appropriate solutions.

Acknowledging tension between value frames is an essential capability to facilitate radical thinking around new solutions to existing problems (Driessen and Hillebrand, 2013). If a partnership 
process is conceptualized as fundamentally non-conflictual in nature this "risks the de-legitimization of conflictual approaches to environmental action, and a retreat from radical thinking and innovative environmental solutions" (Poncelet, 2001, p.13). Once this tension is acknowledged, stakeholders can co-create solutions which deliver benefits to all parties involved, where 'co-creation' has been defined in the broader literature as working together to redefine what is valued and expected or desired on individual and collective bases (Vargo and Lusch, 2011). Le Ber \& Branzei (2010) describe this hybridization process, which they term 'value frame fusion' as stakeholders initially contrasting their divergent understanding of a problem ('diagnostic frames') and then working together to deliberately develop a partnership-specific understanding of possible solutions ('prognostic frame').

\section{TABLE 7}

Systemized learning. This second-order engagement learning capability concerns how the organization learns to learn from its stakeholder engagement activities. Guided by prior research into second-order capabilities in the context of alliance management (Schilke, 2014), evidence was sought relating to how companies analyze and codify their past experience of what works and what does not in relation to their first-order engagement management capabilities, and then transfer relevant knowledge within the organization. Table 8 summarizes key insights from the review relating to this systemized learning capability. Although the articles reviewed refer to this positive feedback loop between stakeholder engagement, innovation and learning (Ayuso et al., 2011; BlumKusterer and Hussain, 2001; Klewitz and Hansen, 2014; Sharma and Vrendenburg, 1998), there is a need for more research on the interaction between stakeholder engagement capabilities and the management of the knowledge gained from that engagement (Ayuso et al., 2011). Drawing on the indicative evidence from the literature review, three broad dimensions of a systematized learning capability are inferred: accumulating experiences, embedding integrative routines and organizing for continuous learning. 
Accumulating experiences. Organizations learn to integrate multiple stakeholder issues over time by accumulating experiences, making this capability difficult to build overnight or copy (Driessen and Hillebrand, 2013). These experiences can be from individuals within the firm, from previous innovation projects, and from benchmarking what other companies are doing. Rather than the insight residing only with the team which owns that stakeholder relationship (e.g. sustainability teams for NGOs, marketing for customers, and public affairs for policymakers), firms need to be able to aggregate this learning at an organizational level.

Embedding integrative routines. Next, organizations need to embed the learning from these experiences across the organization. This includes reflecting on what works with respect to stakeholder engagement, and sharing and embedding that across the organization (Ayuso et al., 2006, 2011; de Medeiros et al., 2014), albeit not in such a rigid way as to reduce the opportunity for future learning. For example, Unilever develops online resources including case studies and best practice guides relating to sustainability initiatives (www.unilever.com).

Organizing for continuous learning. This capability involves achieving an organizational context (comprising structure, physical resources, individual actors and culture) which is open and flexible enough to allow the management of external stakeholder relationships to continuously evolve in response to what has previously been learnt. A similar capability has been termed "knowledge reconfiguration" in the product innovation literature, defined as "the creation of an 'open' structure that makes it possible to redefine role systems and relational patterns in a flexible way in order to make it easier to recombine resources continuously" (Verona and Ravasi, 2002, p.579). The review suggests that, in the context of environmental innovation, this could include reconfiguring the supply chain to enable reverse logistics for end-of-life product take-back (Roy and Whelan, 1992), or changing the organizational structure (Horbach, 2008) particularly to a non-hierarchical structure that favours direct communication and proximity between people (Ayuso et al., 2006). It also involves providing "flexible structures and systems that facilitate the development of new ideas" (Ayuso et al., 2006, p.485) and "an organizational context to support experimentation and the 
seeking of opportunities at the business/natural environment interface....through employee compensation systems and by facilitating management discretion" (Sharma and Vrendenburg, 1998, p.742).

\section{TABLE 8}

\section{Operational capabilities}

Operational capabilities are the basic technical capabilities a firm must develop to support stakeholder engagement in environmental innovation. Verona's (1999) model identified marketing and technological capabilities. The review provided evidence that marketing capability needs to be enhanced in the context of environmental innovation with an additional environmental capability. There was empirical evidence in the articles that technological capability triggers environmental innovation (Horbach, 2008), however no evidence was found to support changing the articulation of technological capability from Verona (1999), which therefore remains unchanged in this articles' conceptualisation, as discussed next.

Technological capability. Verona (1999) lists four dimensions of technological capabilities: scientific expertise, manufacturing, design and technological complementarities. He cites studies which show that these underlying dimensions of technological capability are important drivers of innovation outcomes, even though dynamic capabilities may be required to deploy or recombine them in a new way. Similarly, these dimensions of technological capabilities are relevant to the framework to the extent that they are drawn on, in combination with dynamic engagement capabilities, to deliver innovations involving stakeholder engagement.

Marketing capability. The review literature reports that marketing activities, such as clear project definition, good market analysis, marketing research, and sales forecasting to gain a clear understanding of users' needs and wants, are as crucial for environmentally-friendly new products as they are for traditional new product development (Pujari et al., 2004). However, in the context of environmental innovation, marketers need to provide and access information from a broader set of internal and external stakeholders (Mariadoss et al., 2011; Polonsky and Ottman, 1998) without 
filtering the incoming information based on their 'marketing' value frame (Aschehoug et al., 2012), and must be more open to addressing the needs of this broader stakeholder set (Polonsky and Ottman, 1998). The need to build relationships and networks with stakeholders is even more important for process and organizational innovations than it is for new products (Mariadoss et al., 2011). Table 9 summarises key insights from the review articles relating to marketing capability.

\section{TABLE 9}

Environmental capability. Three dimensions of environmental capability were identified from the reviewed literature (see Table 10 for details). The first is providing environmental expertise, for example relating to clean technology and manufacturing processes (Dangelico and Pujari, 2010). The second is monitoring and communicating environmental performance, which includes environmental benchmarking, performance target-setting and measurement processes, environmental database management (Pujari et al., 2003), and internal and external reporting and communication. Finally, championing environmental sustainability takes such forms as building businesses cases, providing cross-functional project management (Pujari et al., 2003), and influencing employees and decision-makers. Table 10 summarises key insights from the review articles relating to environmental capability.

\section{TABLE 10}

\section{Outcomes and benefits}

As discussed in the descriptive analysis, the primary outcome of stakeholder engagement in the review articles was environmental innovation across the three categories identified in Klewitz and Hansen's (2014) review - product, process and organizational. The literature also discussed a range of benefits expected to accrue to organizations who engage with stakeholders in these innovations, which are presented in Table 11. However, no empirical evidence was found of the link between capabilities and outcomes. Different types of environmental innovation may demand different capabilities, depending on the complexity and diversity of the stakeholder perspectives which need to be integrated. Existing categorizations of environmental innovations may be of limited use in 
defining the capabilities required. For example, some process innovations may be wholly in the firm's control, whereas others may involve multiple supply-chain partners, and some product innovations may be simple and easily understood by customers (e.g. recycled kitchen towel), or very complex requiring changes to national networks and consumer behaviour patterns (e.g. electric cars). An opportunity exists then to clarify the link between the types of environmental innovation and the capabilities they require.

\section{TABLE 11}

\section{DISCUSSION}

Taking a dynamic capabilities perspective on stakeholder engagement for innovation, and situating this articles contributions in the environmental innovation context not only addresses a critical global challenge in practice, but also embodies scholarly interest in open (or distributed and democratized) forms of innovation (West et al., 2014) and co-creation (Payne et al., 2008), and thereby broadens the scope for innovation studies (Johnson and Christensen, 2008). This research contributes to an understanding of the capabilities required to successfully engage stakeholders in the environmental innovation process. Engaging with stakeholders to drive environmental innovation requires three levels of capabilities: operational capabilities, first-order engagement management capabilities, and second-order engagement learning capabilities. This article identifies and elaborates the dimensions of these capabilities with examples from 88 academic articles (Tables 5-10).

Recent stakeholder engagement literature shows that companies which move from informing stakeholders to involving stakeholders develop internal capabilities that reduce their resourcedependence uncertainty (Herremans et al., 2016), and suggests stakeholder relationships can deliver innovative 'win-win' solutions (Eccles et al., 2014). Prior sustainability innovation literature has taken a dynamic capabilities perspective on stakeholder dialogue (Ayuso et al., 2006) but has not explored second-order capabilities in this context. Dynamic capability literature has focused mostly on the interplay between first-order and second-order capabilities in the setting of alliance management (Schilke, 2014). This research adds granularity to and provides evidence of the 
dynamic capabilities involved in the process of integrating external knowledge sources (West and Bogers, 2014) in the environmental innovation context, where these sources are more diverse and likely to exhibit different and potentially conflicting value frames. This work therefore contributes to the stakeholder engagement literature with insights into how discord or difference can be utilized positively (Dawkins, 2015, 2014). Using evidence from the reviewed articles, we refine understanding of the operational and first-order engagement management capabilities required for stakeholder engagement in environmental innovation, and contribute to theory by identifying two second-order engagement learning capabilities. The framework presented in this article provides a starting point for further research into the relationship between first-order and second-order dynamic capabilities in the environmental innovation context, which may also be transferable to other open innovation contexts.

Evidence is presented to suggest that a second-order value framing capability underpins an organization's capability to learn from its stakeholder engagement. Value framing is the capability to navigate between the different ways of seeing the world that exist between different social groupings so that organizations can think beyond the immediate boundaries of the innovation context they are looking at, to learn to understand the alternative value frames of their potential collaborators, and co-create novel solutions which harness those differences by rethinking (and reframing) the problem, or combining competencies in new ways. By identifying value framing as a second-order capability the authors respond to the call for research to look at institutional theory to increase understanding of how dynamic capabilities develop (Schilke, 2014).

The review included articles addressing the 'value frame fusion' which occurs in cross-sector relationships between firms and NGOs (Le Ber and Branzei, 2010; Holmes and Smart, 2009). However, more research is needed to classify and explore the instances of competing value frames which arise between firms and other external stakeholder groups, and between groups or departments within the firm, and to understand what is done at an individual, group and organizational level to navigate these differences. It could be useful to evaluate how a company's 
institutional approach to stakeholder engagement is interpreted and implemented at the project level. Most articles in this review take the firm as their unit of analysis (exceptions are Dangelico and Pujari, 2010; Dangelico et al., 2013; Heiskanen and Lovio, 2010; Hoffmann, 2007), suggesting an assumption that an organization's stakeholder engagement approaches are implemented consistently across the organization. This assumption could be researched by looking at how capabilities manifest themselves in diverse projects within the same organization, which could be influenced, for example, by the value frame of the department, or project manager.

Evidence is also presented that a further second-order capability, systematized learning, is needed to enable organizations to learn from stakeholder engagement through specific individuals working on discrete innovation projects, who then share that learning across the organization, and by creating organizational structures and processes which support the continuous reconfiguration of externally-sourced knowledge, so that the organization is 'learning to learn' and continually developing its stakeholder engagement capabilities. This corresponds closely with Zollo and Winter's (2002) notion of 'deliberate learning,' and aligns with research in the dynamic capabilities field which suggests that systematic approaches are required to translate 'raw experience' into 'relational capabilities' - a type of dynamic capability "with the capacity to purposefully create, extend, or modify the firm's resource base, augmented to include the resources of its alliance partner" (Helfat et al., 2007, p.66). These systematic approaches are "active learning processes using systematic ways of developing people and gaining tacit knowledge, followed by knowledge codification and internalization" (Helfat et al., 2007, p.72). Further research is needed into how organizations systematically learn from engaging their stakeholders and embed what they learn into their environmental innovation processes.

By pointing to the close link between value framing and systematized learning, this research builds on evidence (Lane and Lubatkin, 2016) that inter-organizational learning is dependent (inter alia) on the similarity, or differences, in the value frames (or dominant logics) of the organizations working together. It is further argued that organizations with a value framing capability have greater 
potential to achieve 'higher order' learning because they are able to question the existing boundary conditions, frames or assumptions of the problems at hand (Quist and Tukker, 2013). Reay and Hinings (2009) propose that rivalry between competing logics is resolved through collaboration at micro levels but that it is "possible to create new institutional arrangements where more than one logic guides the behaviour of actors within an organizational field" (p.647). Further research is needed to explore the link between these second-order capabilities, and how a value framing capability works at the individual, group and institutional level.

This research also suggests a bi-directional interaction between operational and dynamic capabilities. The capabilities literature has long focused on the one-way impact of dynamic capabilities on operational capabilities. This has left unexplored the reverse effects which might manifest as the routinization and transcendence of certain operational capabilities to become potential dynamic capabilities (Helfat et al., 2007; Newey and Zahra, 2009; di Stefano et al., 2014). This includes its newly emerging routines, such as sustainability practices. This review finds some evidence of operating capabilities having an impact on the effectiveness of dynamic capabilities in this way. Part of the environmental capability includes providing cross-functional project management (Pujari et al., 2003), and influencing employees and decision-makers. Marketing capability can also help develop stakeholder engagement capability through interacting more broadly and deeply with stakeholders including, but not limited to, customers. In this way, operational capabilities can be seen as playing a role in developing dynamic stakeholder engagement capabilities. Examples of this in practice could include sustainability experts participating in external networks addressing environmental issues, or marketing professionals sharing outputs from customer focus groups relating to more environmentally-friendly products or services with external stakeholder groups, as well as across internal teams.

Although in some organizations there is a centralized functional team (CSR, environment or sustainability team), it is often a distributed capability which is located within several departments. This might take the form, for example, of sustainability steering groups or working groups composed 
of representatives from multiple functions; sustainability or environmental specialists embedded in other functions such as product development, marketing/communications, supply chain, operations and property; and employees acting informally as 'green champions' across the organization. This suggests that sustainability professionals are well positioned to support the development of stakeholder engagement capabilities. The sustainability marketing literature argues that marketing has a significant role in sustainability innovation (Sharma and Vrendenburg, 1998; Sheth et al., 2010; Vargo and Lusch, 2004). Future research in this field could examine in more detail how sustainability and marketing can exploit their traditional operational capabilities to enable stakeholder engagement in environmental innovation.

Finally, the authors suggest that the capabilities framework presented in this article, and the related contributions discussed above, can extend beyond the specific context of environmental innovation to contribute to understanding of the capabilities required to engage stakeholders in cocreation and other open innovation settings.

\section{Managerial implications}

Organizations must consider not only which external stakeholders they engage with and how to navigate their interactions, but just as importantly, how to assimilate, interpret and learn from them to build internal capability. In many organizations, stakeholder engagement activities are siloed. The sustainability team/professional may lead the organization's engagement in cross-industry environmental networks and manage partnerships with NGOs. The marketing team own customer relationships and are expert in gathering insight, but may not consider early-stage research on more sustainable products to be a priority. The investor relations team deals with shareholders, and may not pass on signals about the priorities of responsible investors to others in the organization. $R \& D$ and innovation teams may be service providers to brand teams, and therefore not be free to respond to the sustainability trends they identify from competitors, suppliers or entrepreneurial innovators. Efforts are being made to achieve integration at board level through governance structures. However, this internal integration process needs to extend down the organization with the integration 
of operational activities across other parts of the business. For example, British retailer Argos included objectives for packaging reduction (sustainability team-led) in an inter-product selection process (commercial buying team-led) (Argos Ltd, personal communication).

Firms need to be conscious of the potential for competing value frames to exist between different functional groups within the firm, and find ways to harness these differences in order to achieve a common understanding and interpretation of the insight sourced from external stakeholders and what this might mean for the organization. Similarly, an organization's external stakeholder engagement must be an ongoing process for the stakeholders to fully achieve mutual understanding and learning. Many firms carry out periodic consultation exercises, often outsourced to specialist sustainability consultancies, which involve short conversations with representatives from various stakeholder groups to identify the range of stakeholder issues facing that organization. For many firms this has developed into the formation of stakeholder panels or advisory boards who sit perhaps bi-annually to review the organization's sustainability progress. However, this still does not amount to the 'relational work' required to collaborate for systemic change (Senge et al., 2007). It is the investment in this relational work which allows differences in value frames between firms and stakeholders to be understood and reflected on, and for new ways of understanding and doing to be mutually created.

\section{LIMITATION AND FUTURE RESEARCH}

This research responds to calls for better understanding about how firms can effectively integrate stakeholder perspectives into their innovation processes, particularly in the context of environmental innovation. It synthesizes existing knowledge in this field and develops a hierarchical capabilitybased framework for engaging stakeholders in environmental innovation, created by moving iteratively between the review data, a prior model of stakeholder integration in new product development, and broader literature on dynamic capabilities, organizational learning, absorptive capacity and institutional logics. A partial response to the question of 'How firms engage with their

stakeholders, from distinct institutional settings, to enable environmental innovation?' can be addressed in terms of the structures and processes an organization deploys to manage its stakeholder 
engagement. However, this needs to be complemented with the cultural appreciation and relational assets required to harness the differences in the values, objectives, motivations and competencies of institutionally distinct stakeholder groups, together with a way of translating learning on a local level to how best to do this at the organizational level. This points to a need for more research on the two second-order dynamic capabilities revealed by this research - value framing and systematized learning. In depth qualitative research into partnerships between organizations and external stakeholders, across diverse innovation projects with different types of stakeholder, would be useful to explore the instances of competing value frames which arise, and to understand the strategies and mechanisms employed at an individual, group and organizational level to navigate these differences. Future research could also explore how organizations systematically learn from engaging their stakeholders and embed new knowledge into their environmental innovation processes. Longitudinal studies of such partnerships could reveal how these two second-order capabilities evolve over time within partnership dyads.

The framework was informed by a systematic review of the literature relating to stakeholder engagement in environmental innovation. However, since this context is representative of the challenges posed by increasingly inclusive innovation practices with extensive and diverse sets of external and internal stakeholders, it also provides a useful organizing lens for further research on more distributed and democratized models of innovation. Such research could look at the role of first-order engagement management and second-order engagement learning capabilities in the implementation of open innovation or collaborative innovation projects.

\section{REFERENCES}

*denotes articles included in the systematic review referenced in this article ( 75 articles). A further 13 articles making up the balance of the review are not referenced directly in this article due to space limitations. A list of these remaining articles in available on request from the authors

Adams, R.,S. Jeanrenaud, J. Bessant, D. Denyer and P. Overy (2016) 'Sustainability-oriented Innovation: A Systematic Review’, International Journal of Management Reviews, 18(2), pp. $180-205$. 
*Albino, V., R.M. Dangelico and P. Pontrandolfo (2012) 'Do inter-organizational collaborations enhance a firm's environmental performance? A study of the largest U.S. companies.', Journal of Cleaner Production, 37, pp. 304-315.

Ambrosini, V. and C. Bowman (2009) 'What are dynamic capabilities and are they a useful construct in strategic management?', International Journal of Management Reviews, 11(1), pp. 29-49.

*Anttonen, M., M. Halme, E. Houtbeckers, and J. Nurkka (2013) 'The other side of sustainable innovation: is there a demand for innovative services?', Journal of Cleaner Production, 45, pp. 89-103.

Argyris, C. and D.A. Schön (1978) Organizational Learning: A Theory of Action Perspective.

*Aschehoug, S.H., C. Boks, and S. Støren (2012) 'Environmental information from stakeholders supporting product development.', Journal of Cleaner Production, 31, pp. 1-13.

*Ayuso, S., M.Á., R. Rodríguez, R García-Castro and M.Á. Ariño (2011) 'Does stakeholder engagement promote sustainable innovation orientation?', Industrial Management \& Data Systems, 111(9), pp. 1399-1417.

*Ayuso, S., M.Á. Rodríguez and J.E. Ricart (2006) 'Using stakeholder dialogue as a source for new ideas: a dynamic capability underlying sustainable innovation', Corporate Governance, 6(4), pp. 475-490.

Bansal, P. and K. Roth (2000) 'Why Companies Go Green: a Model of Ecological Responsiveness.', Academy of Management Journal, 43(4), pp. 717-736.

Barnett, M.L. (2007) 'Stakeholder Influence Capacity and the Variability of Financial Returns To Corporate Social Responsibility.', Academy of Management Review, 32(3), pp. 794-816.

*Bartlett, D. (2009) 'Embedding corporate responsibility: the development of a transformational model of organizational innovation', Corporate Governance, 9(4), pp. 409-420.

Battilana, J. and S. Dorado (2010) 'Building Sustainable Hybrid Organizations : the Case of Commercial Microfinance Organizations’, Academy of Management Executive, 53(6), pp. 1419-1440.

*Le Ber, M.J. and O. Branzei (2010) 'Value Frame Fusion in Cross Sector Interactions.', Journal of Business Ethics, 94(S1), pp. 163-195.

*Blum-Kusterer, M. and S.S.Hussain (2001) 'Innovation and corporate sustainability: An investigation into the process of change in the pharmaceuticals industry.', Business Strategy \& the Environment, 10(5) John Wiley \& Sons, Inc., pp. 300-316.

*Bocken, N.M.P., M. Farracho, R. Bosworth, and R. Kemp (2014) 'The front-end of ecoinnovation for eco-innovative small and medium sized companies', Journal of Engineering and Technology Management, 31 Amsterdam, p. 43.

*Van Bommel, H.W.M. (2011) 'A conceptual framework for analyzing sustainability strategies in industrial supply networks from an innovation perspective.', Journal of Cleaner Production, 19(8), pp. 895-904.

Bondy, K. and H. Wilson (2013) 'Individual approaches to reconciling competing logics: A corporate social responsibility case study', EBEN 2013 Conference Lille.

*Bönte, W. and C. Dienes (2013) 'Environmental Innovations and Strategies for the Development of New Production Technologies: Empirical Evidence from Europe.', Business Strategy \& the Environment, 22(8), pp. 501-516. 
*Bos-Brouwers, H.E.J. (2010) 'Corporate Sustainability and Innovation in SMEs: Evidence of Themes and Activities in Practice.', Business Strategy \& the Environment, 19(7), pp. 417-435.

*Carrillo-Hermosilla, J., P. del Río, and T. Könnölä (2010) 'Diversity of eco-innovations: Reflections from selected case studies.', Journal of Cleaner Production, 18(10-11), pp. 10731083.

*Chang, J. and M.J. Lin (2014) 'Collaboration and the performance of green innovation: Investigating the moderation effects of green knowledge integration mechanisms', Global Conference on Business \& Finance Proceedings, 9(1), pp. 344-349.

Chesbrough, H. (2012) 'Open Innovation: Where We've Been and Where We're Going', Research-Technology Management, 55(4), pp. 20-27.

Cohen, W.M. and D.A. Levinthal (1990) 'Absorptive capacity: A new perspective on learning and innovation', Administrative Science Quarterly, 35, pp. 128-152.

Collis, D.J. (1994) 'Research Note: How Valuable are Organizational Capabilities?', Strategic Management Journal, 15(S1), pp. 143-152.

Crossan, M.M., H.W. Lane, and R.E. White (1999) 'An Organizational Learning Framework: From Intuition to Institution', The Academy of Management Review, 24(3), p. 522.

* Dangelico, R.M., P. Pontrandolfo, and D. Pujari (2013) 'Developing Sustainable New Products in the Textile and Upholstered Furniture Industries: Role of External Integrative Capabilities', Journal of Product Innovation Management, 30(4), pp. 642-658.

*Dangelico, R.M. and D. Pujari (2010) 'Mainstreaming Green Product Innovation: Why and How Companies Integrate Environmental Sustainability', Journal of Business Ethics, 95(3) Dordrecht, pp. 471-486.

Danneels, E. (2002) 'The dynamics of product innovation and firm competences', Strategic Management Journal, 23(12), pp. 1095-1121.

Dawkins, C.E. (2015) 'Agonistic Pluralism and Stakeholder Engagement', Business Ethics Quarterly, 25(01), pp. 1-28.

Dawkins, C.E. (2014) 'The Principle of Good Faith: Toward Substantive Stakeholder Engagement', Journal of Business Ethics, 121(2), pp. 283-295.

*De-Burgos-Jiménez, J., D.A. Vazquez-Brust and J.A. Plaza-Úbeda (2011) 'Adaptability, Entrepreneurship and Stakeholder Integration: Scenarios and Strategies for Environment and Vulnerability', Journal of Environmental Protection, 2(10), pp. 1375-1387.

*Delmas, M. and M.W. Toffel (2004) 'Stakeholders and environmental management practices: An institutional framework', Business Strategy and the Environment, 13, pp. 209-222.

Dixon-Woods, M., S. Agarwal, B. Young, D. Jones, and A. Sutton (2004) Integrative approaches to qualitative and quantitative evidence.Agency, H. D. (ed.) London.

Donaldson, T. and L.E. Preston (1995) 'The Stakeholder Theory of the Corporation: Concepts, Evidence, and Implications.', Academy of Management Review, 20(1), pp. 65-91.

*Driessen, P.H. and B. Hillebrand (2013) 'Integrating Multiple Stakeholder Issues in New Product Development: An Exploration', Journal of Product Innovation Management, 30(2), pp. 364 379. 
Eccles, R.G., I. Ioannou, and G. Serafeim (2014) 'The Impact of Corporate Sustainability on Organizational Processes and Performance', Management Science, 60(November), pp. 28352857.

*Foxon, T. and P. Pearson (2008) 'Overcoming barriers to innovation and diffusion of cleaner technologies: Some features of a sustainable innovation policy regime.', Journal of Cleaner Production, 16(1), pp. 148-161.

Friedland, R. and R. Alford (1991) 'Bringing society back in: Symbols, practices and institutional contradictions', in Powell, W.W. and P.J. DiMaggio (eds.) The new institutionalism in organizational analysis. Chicago: University of Chicago Press, pp. 232-266.

Gioia, D.A., K.G. Corley, and A.L. Hamilton, (2012) 'Seeking Qualitative Rigor in Inductive Research: Notes on the Gioia Methodology', Organizational Research Methods, 16(1), pp. 1531.

*Gmelin, H. and S. Seuring (2014) 'Determinants of a sustainable new product development.', Journal of Cleaner Production, 69, pp. 1-9.

*Gonzalez-Padron, T.L. and R.W. Nason (2009) 'Market Responsiveness to societal interests.', Journal of Macromarketing, 29(4), pp. 392-405.

*Guiltinan, J. (2009) 'Creative Destruction and Destructive Creations: Environmental Ethics and Planned Obsolescence.', Journal of Business Ethics, 89(S1), pp. 19-28.

*Hallstedt, S., H. Ny, K.-H. Robèrt and G Broman (2010) 'An approach to assessing sustainability integration in strategic decision systems for product development', Journal of Cleaner Production, 18(8), pp. 703-712.

*Hansen, E.G. and F. Grosse-Dunker (2009) 'Sustainability innovation cube - A framework to evaluate sustainability-oriented innovations', International Journal of Innovation Management, 13(4), pp. 683-713.

*Hansen, E.G. and J. Klewitz (2012) 'The Role of an SME's Green Strategy in Public-Private Eco-innovation Initiatives: The Case of Ecoprofit.', Journal of Small Business \& Entrepreneurship, 25(4), pp. 451-477.

Hart, S.L. (1995) 'A Natural-Resource-Based View of the Firm', The Academy of Management Review, 20(4), pp. 986-1014.

Hart, S.L. (1997) 'Beyond Greening: Strategies for a Sustainable World', Harvard Business Review, 75(1), pp. 66-76.

Hart, S.L. and S. Sharma (2004) 'Engaging fringe stakeholders for competitive imagination.', Academy of Management Executive, 18(1), pp. 7-18.

*Heiskanen, E. and R. Lovio (2010) 'User-Producer Interaction in Housing Energy Innovations: Energy Innovation as a Communication Challenge', Journal of Industrial Ecology, 14(1) New Haven, pp. 91-102.

Helfat, C., S. Finkelstein, W. Mitchell, M.A. Peteraf, H. Singh, D.J. Teece and S.G. Winter (2007) 'Dynamic Capabilities: Foundations', in Helfat, C., S. Finkelstein, W. Mitchell, M.A. Peteraf, H. Singh, D.J. Teece and S.G. Winter (eds.) Dynamic Capabilities: Understanding Strategic Change in Oganizations. Oxford: Blackwell Publishing Ltd., pp. 1-18.

Henisz, W.J., S. Dorobantu and L.J. Nartey (2014) 'Spinning Gold: The Financial Returns to Stakeholder Engagement', Strategic Management Journal, 35, pp. 1727-1748. 
Herremans, I.M., J. A Nazari and F. Mahmoudian (2016) 'Stakeholder Relationships, Engagement, and Sustainability Reporting', Journal of Business Ethics, 138(3), pp. 417-435.

Hill, C.W.L. and T.M. Jones (1992) 'Stakeholder-Agency Theory', Journal of Management Studies, 29(2), pp. 130-154.

Von Hippel (2005) Democratizing Innovation. Cambridge, MA: MIT Press.

*Hoffmann, E. (2007) 'Consumer integration in sustainable product development.', Business Strategy \& the Environment, 16(5), pp. 322-338.

*Holmes, S. and P. Smart (2009) 'Exploring open innovation practice in firm-nonprofit engagements: a corporate social responsibility perspective.', R\&D Management, 39(4), pp. 394-409.

*Holweg, M. (2014) 'Where Firm-Level Innovation and Industrial Policy Meet: Consensus Roadmaps for Low-Carbon Powertrain Technologies.', Journal of Product Innovation Management, 31(1), pp. 33-42.

*Horbach, J. (2008) 'Determinants of environmental innovation-New evidence from German panel data sources', Research Policy, 37(1), pp. 163-173.

*Jamali, D., M. Yianni and H. Abdallah (2011) 'Strategic partnerships, social capital and innovation: accounting for social alliance innovation.', Business Ethics: A European Review, 20(4), pp. 375-391.

Jay, J. (2013) 'Navigating paradox as a mechanism of change and innovation in hybrid organizations', Academy of Management Journal, 56(1), pp. 137-159.

Johnson, M.W. and C.M. Christensen (2008) 'Reinventing your business model', Harvard Business Review, (December), pp. 50-60.

Kale, P. and H. Singh (2007) 'Building firm capabilities through learning: The role of the alliance learning process inalliance capabilities and firm-level alliance success', Strategic Management Journal, 28, pp. 981-1000.

*Kammerer, D. (2009) 'The effects of customer benefit and regulation on environmental product innovation.: Empirical evidence from appliance manufacturers in Germany', Ecological Economics, 68(8/9) Elsevier B.V., pp. 2285-2295.

Kemp, R. and P. Pearson (2008) Final Report MEI project about measuring eco-innovation. http://www.oecd.org/env/consumption-innovation/43960830.pdf

*Kiron, D. (2012) 'The Four Organizational Factors that Built Kimberley-Clarks Remarkable Sustainability Goals', MIT Sloan Management Review, 53(53420) Cambridge: Massachusetts Institute of Technology, pp. 1-3.

*Kiron, D., N. Kruschwitz, M. Reeves and E. Goh (2013) 'The Benefits of Sustainability-Driven Innovation', MIT Sloan Management Review, 54(2), pp. 69-73.

*Klewitz, J. and E.G. Hansen (2014) 'Sustainability-oriented innovation of SMEs: a systematic review', Journal of Cleaner Production, 65, pp. 57-75.

*Klewitz, J., A. Zeyen and E.G. Hansen (2012) 'Intermediaries driving eco-innovation in SMEs: a qualitative investigation', European Journal of Innovation Management, 15(4), pp. 442-467.

*Könnölä, T. and G.C. Unruh (2007) 'Really changing the course: the limitations of environmental management systems for innovation.', Business Strategy \& the Environment, 16(8), pp. 525-537. 
*Kourula, A. and M. Halme (2008) 'Types of corporate responsibility and engagement with NGOs: an exploration of business and societal outcomes.', Corporate Governance: The International Journal of Effective Board Performance, 8(4), pp. 557-570.

*De Kraker, J., R. Cörvers, P. Valkering, M. Hermans and J. Rikers, (2013) 'Learning for sustainable regional development: towards learning networks 2.0?', Journal of Cleaner Production, 49, pp. 114-122.

*Kruschwitz, N. and J. Pflueger (2012) 'How Dell Turned Bamboo and Mushrooms Into Environmental-Friendly Packaging', MIT Sloan Management Review, 54(1), pp. 1-5.

Lane, P.J. and M. Lubatkin (1998) 'Relative Absorptive Capacity and Interorganizational Learning', Strategic Management Journal, 19(5), pp. 461-477.

*Laperche, B. and D. Uzunidis (2012) 'Eco-Innovation, Knowledge Capital and the Evolution of the Firm', IUP Journal of Knowledge Management, 10(3), pp. 14-34.

*Lee, K.-H. and J.-W. Kim (2011) 'Integrating Suppliers into Green Product Innovation Development: an Empirical Case Study in the Semiconductor Industry.', Business Strategy \& the Environment, 20(8), pp. 527-538.

*Lenox, M. and J. Ehrenfeld (1997) 'Organizing for effective environmental design', Business Strategy and the Environment, 6, pp. 187-196.

*Liao, C.-S., K.-R. Lou and C.-T. Gao (2013) 'Sustainable Development of Electrical and Electronic Equipment: User-driven Green Design for Cell Phones.', Business Strategy \& the Environment, 22(1), pp. 36-48.

*Luo, X. and C.B. Bhattacharya (2009) 'The Debate over Doing Good: Corporate Social Performance, Strategic Marketing Levers, and Firm-Idiosyncratic Risk.', Journal of Marketing, 73(6) American Marketing Association, pp. 198-213.

Macdonald, E.K., M. Kleinaltenkamp and H.N. Wilson (2016) 'How Business Customers Judge Solutions: Solution Quality and Value in Use', Journal of Marketing, 80(May 16), pp. 92-120.

*Von Malmborg, F. (2007) 'Stimulating learning and innovation in networks for regional sustainable development: the role of local authorities.', Journal of Cleaner Production, 15(17), pp. $1730-1741$.

*De Marchi, V. (2012) 'Environmental innovation and R\&D cooperation: Empirical evidence from Spanish manufacturing firms.', Research Policy, 41(3), pp. 614-623.

*De Marchi, V.and R. Grandinetti (2013) 'Knowledge strategies for environmental innovations: the case of Italian manufacturing firms.', Journal of Knowledge Management, 17(4), pp. 569582.

*Mariadoss, B.J., P.S. Tansuhaj and N. Mouri (2011) 'Marketing capabilities and innovationbased strategies for environmental sustainability: An exploratory investigation of B2B firms', Industrial Marketing Management, 40(8), pp. 1305-1318.

*Mathur, V.N., A.D.F. Price and S. Austin (2008) 'Conceptualizing stakeholder engagement in the context of sustainability and its assessment.', Construction Management \& Economics, 26(6) Routledge, pp. 601-609.

Mays, N., C. Pope and J. Popay (2005) 'Systematically reviewing qualitative and quantitative evidence to inform management and policy-making in the health field.', Journal of Health Services Research \& Policy, 10 Suppl 1, pp. 6-20. 
*McDonald, S. and S. Young (2012) 'Cross-sector collaboration shaping Corporate Social Responsibility best practice within the mining industry.', Journal of Cleaner Production, 37, pp. $54-67$.

*De Medeiros, J.F., J.L.D. Ribeiro and M.N. Cortimiglia (2014) 'Success factors for environmentally sustainable product innovation: a systematic literature review.', Journal of Cleaner Production, 65, pp. 76-86.

Meyer, R. and G. Hammerschmid (2006) 'Changing Institutional Logics and Executive Identities : A managerial challenge to public administration in Austria', American Behavioural Scientist, 49(7), pp. 1000-1014.

*Murphy, M. and D.Arenas (2011) 'Through Indigenous Lenses: Cross-Sector Collaborations with Fringe Stakeholders', Journal of Business Ethics, 94(S1), pp. 103-121.

*Nakata, C. and K. Weidner (2012) 'Enhancing New Product Adoption at the Base of the Pyramid: A Contextualized Model.', Journal of Product Innovation Management, 29(1) WileyBlackwell, pp. 21-32.

Newey, L.R. and S. A. Zahra (2009) 'The evolving firm: How dynamic and operating capabilities interact to enable entrepreneurship', British Journal of Management, 20(SUPP. 1), pp. S81S100.

Nonaka, I. (1991) 'The Knowledge-Creating Company', Harvard Business Review, (NovemberDecember), pp. 162-171.

O'Riordan, L. and J. Fairbrass (2014) 'Managing CSR Stakeholder Engagement: A New Conceptual Framework', Journal of Business Ethics, 125(1), pp. 121-145.

OECD (2005) Oslo manual: Guidelines for collecting and interpreting innovation data. Paris: Organisation for Economic Co-operation and Development : Statistical Office of the European Communities.

Oliver, C. (1991) 'Strategic responses to institutional pressures', The Academy of Management Review, 16(1), pp. 145-179.

*Oxborrow, L. and C. Brindley (2013) 'Adoption of "eco-advantage” by SMEs: emerging opportunities and constraints', European Journal of Innovation Management, 16(3) Bradford: Emerald Group Publishing, Limited, pp. 355-375.

Payne, A.F., K. Storbacka and P. Frow (2008) 'Managing the co-creation of value', Journal of the Academy of Marketing Science, 36(1), pp. 83-96.

*Petruzzelli, A.M., R.M. Dangelico, D. Rotolo and V. Albino (2011) 'Organizational factors and technological features in the development of green innovations: Evidence from patent analysis', Innovation: Management, Policy and Practice, 13(3), pp. 291-310.

Pittaway, L., M. Robertson, K. Munir, D. Denyer and A. Neely (2004) 'Networking and innovation: a systematic review of the evidence', International Journal of Management Reviews, 5-6(3-4), pp. 137-168.

*Polonsky, M.J. and J. Ottman (1998) 'Stakeholders' Contribution to the Green New Product Development Process.', Journal of Marketing Management, 14(212) Routledge, pp. 533-557.

*Poncelet, E.C. (2001) “"A Kiss Here and a Kiss There”: Conflict and Collaboration in Environmental Partnerships', Environmental Management, 27(1), pp. 13-25.

Porter, M. and M.R. Kramer (2006) 'Strategy and society: The link between competitive advantage and corporate social responsibility’, Harvard Business Review 
Porter, M.E. and M.R. Kramer (2011) 'Creating Shared Value: How to reinvent capitalism - and unleash a wave of innovation and growth', Harvard Business Review, 89(1/2), pp. 63-77.

*Pujari, D. (2006) 'Eco-innovation and new product development: understanding the influences on market performance', Technovation, 26(1), pp. 76-85.

*Pujari, D., K. Peattie and G. Wrigh, (2004) 'Organizational antecedents of environmental responsiveness in industrial new product development', Industrial Marketing Management, 33(5), pp. 381-391.

*Pujari, D., G. Wright and K. Peattie (2003) 'Green and competitive: Influences on environmental new product development performance', Journal of Business Research, 56(8), pp. 657-671.

*Quist, J. and A. Tukker (2013) 'Knowledge collaboration and learning for sustainable innovation and consumption: introduction to the ERSCP portion of this special volume.', Journal of Cleaner Production, 48, pp. 167-175.

Reay, T. and C.R. Hinings (2009) 'Managing the Rivalry of Competing Institutional Logics', Organization Studies, 30, pp. 629-652.

Roberts, D.L. and M. Candi (2014) 'Leveraging Social Network Sites in New Product Development : Opportunity or Hype ?', Journal of Product Innovation Management, 31, pp. 113.

Rousseau, D.M., J. Manning and D. Denyer (2008) 'Evidence in management and organizational science: Assembling the field's full weight of scientific knowledge through syntheses', The Academy of Management Annals, 2(1), pp. 475-515.

*Roy, R. and R.C. Whelan (1992) 'Successful Recycling Through Value-Chain Collaboration', Long Range Planning, 25(4), p. 62.

Rust, R.T. and B. Cooil (1994) 'Reliability Measures for Qualitative Data: Theory and Implications', Journal of Marketing Research, XXXI(February), pp. 1-14.

Schilke, O. (2014) 'Second-Order Dynamic Capabilities: How do they matter?', The Academy of Management Perspectives, 28(4), pp. 368-380.

*Senge, P.M., B.B. Lichtenstein, K. Kaeufer, H. Bradbury and J.S. Carroll, (2007) 'Collaborating For Systemic Change', MIT Sloane Manamgement Review, 48(2), pp. 43-53.

*Sharma, S. and H. Vrendenburg (1998) 'Proactive corporate environmental strategy and the development of competitively valuable organizational capabilities', Strategic Management Journal, 19(February), pp. 729-753.

Sheth, J.N., N.K. Sethia and S. Srinivas (2010) 'Mindful consumption: a customer-centric approach to sustainability', Journal of the Academy of Marketing Science, 39(1), pp. 21-39.

Sinkula, J.M. (1994) 'Market Information Processing and Organizational Learning', Journal of Marketing, 58(January), pp. 35-45.

*Slotegraaf, R.J. (2012) 'Keep the Door Open: Innovating Toward a More Sustainable Future.', Journal of Product Innovation Management, 29(3), pp. 349-351.

*Sol, J., P.J. Beers and A.E.J. Wals (2013) 'Social learning in regional innovation networks: trust, commitment and reframing as emergent properties of interaction.', Journal of Cleaner Production, 49, pp. 35-43. 
*Spena, T.R. and A. De Chiara (2012) 'CSR, innovation strategy and supply chain management: toward an integrated perspective', International Journal of Technology Management, 58(1-2), p. 83.

*Stafford, E.R., M.J. Polonsky and C.L. Hartman (2000) 'Environmental NGO-business collaboration and strategic bridging: A case analysis of the Greenpeace-Foron Alliance.', Business Strategy \& the Environment, 9(2), pp. 122-135.

Di Stefano, G., M. Peteraf and G. Verona (2014) 'The Organizational Drivetrain: A Road to Integration of Dynamic Capabilities Research', Academy of Management Perspectives, 28(4), pp. 307-327.

Teece, D.J., G. Pisano and A. Shuen (2007) 'Dynamic capabilities and strategic management', Strategic Management Journal, 18(7), pp. 509-533.

*Theyel, G. and K. Hofmann (2012) 'Stakeholder relations and sustainability practices of US small and medium-sized manufacturers', Management Research Review, 35(12), pp. 1110 1133.

Tranfield, D., D. Denyer and P. Smart (2003) 'Towards a Methodology for Developing EvidenceInformed Management Knowledge by Means of Systematic Review’, British Journal of Management, 14(3), pp. 207-222.

*Triguero, A., L. Moreno-Mondéjar and M.A. Davia (2013) 'Drivers of different types of ecoinnovation in European SMEs.', Ecological Economics, 92, pp. 25-33.

*Urbaniec, M. and W. Gerstlberger (2011) 'Innovation in environment-oriented networks', Management of Environmental Quality, 22(6), pp. 686-704.

Vargo, S.L. and R.F. Lusch (2011) 'It's all B2B... and beyond: Toward a systems perspective of the market', Industrial Marketing Management, 40(2), pp. 181-187.

Vargo, S.L. and R.F. Lusch (2004) 'Evolving to a new dominant logic for marketing', Journal of Marketing, 68(1), pp. 1-17.

*Verghese, K. and H. Lewis (2007) 'Environmental innovation in industrial packaging: a supply chain approach.', International Journal of Production Research, 45(18/19), pp. 4381-4401.

Verona, G. (1999) 'A resource-based view of product development', The Academy of Management Review, 24(1), pp. 132-142.

Verona, G. and D. Ravasi (2002) 'Unbundling dynamic capabilities: An exploratory study of continuous product innovation', Industrial and Corporate Change, 12(3), pp. 577-606.

West, J. and M. Bogers (2014) 'Leveraging external sources of innovation: A review of research on open innovation', Journal of Product Innovation Management, 31(4), pp. 814-831.

West, J., A. Salter, W. Vanhaverbeke and H. Chesbrough (2014) 'Open innovation: The next decade', Research Policy, 43(5), pp. 805-811.

Wilson, H.N. (2004) 'Towards rigour in action research: a case study in marketing planning', European Journal of Marketing, 38(3/4), pp. 378-400.

Winter, S. (2003) 'Understanding dynamic capabilities', Strategic Management Journal, 24(10), pp. 991-995.

World Economic Forum (2014) World Economic Forum. Available at: http://www.weforum.org/issues/sustainable-consumption (Accessed: 25 March 2014). 
*Yarahmadi, M. and P.G. Higgins (2012) 'Motivations towards environmental innovation', European Journal of Innovation Management, 15(4) Bradford: Emerald Group Publishing, Limited, pp. 400-420.

Young, W., K. Hwang, S. Mcdonald, and C.J. Oates (2010) 'Sustainable Consumption: Green Consumer Behaviour when Purchasing Products', Sustainable Development, 31(March 2009), pp. 20-31.

Zahra, S.A, H.J. Sapienza and P. Davidsson (2006) 'Entrepreneurship and Dynamic Capabilities: A Review, Model and Research Agenda.', Journal of Management Studies, 43(June), pp. $917-$ 955.

Zahra, S.A. and G. George (2002) 'Absorptive capacity: a review, reconceptualization, and extension', Academy of management Review, 27(2), pp. 185-203.

Zollo, M. and S.G. Winter (2002) 'Deliberate learning and the evolution of dynamic capabilities', Organization Science, 13(3), pp. 339-351. 
TABLE 1

Search strings

\begin{tabular}{|c|c|}
\hline Theme & Search string \\
\hline Sustainability & $\begin{array}{l}\text { (sustainab* OR environmental OR green OR ecolog* OR CSR OR "corporate social } \\
\text { responsibility" OR "social* responsib*" OR "corporate social performance" OR eco-innovation } \\
\text { OR "green technology" OR renewable* OR remanufacture* OR "triple bottom line" OR eco- } \\
\text { efficien* OR eco-effectiv* OR SDI OR eco?centric OR biomimicry OR "beyond greening" OR } \\
\text { "frugal innovation" OR "reverse innovation" OR "circular economy" OR "closed-loop" OR "life- } \\
\text { cycle analysis" OR "cleaner production" OR "trickle up innovation" OR "cradle-to-cradle" OR } \\
\text { "social innovation" OR "bottom of the pyramid" OR BOP OR ISO 14001) }\end{array}$ \\
\hline Innovation & $\begin{array}{l}\text { (innovat* OR R\&D OR "research and development" OR invent* OR "product development" OR } \\
\text { "new product development" OR NPD OR "value proposition" OR "process innovation" OR } \\
\text { "organi?* innovation) }\end{array}$ \\
\hline Stakeholder & $\begin{array}{l}\text { (stakeholder* OR consumer* OR customer* OR user* OR supplier* OR competitor* OR partner* } \\
\text { OR communit* OR regulator* OR policymaker*OR government OR NGO* OR "non- } \\
\text { governmental organi?ation" OR media OR employee* OR director* OR department* OR } \\
\text { investor* OR entrepreneur*) }\end{array}$ \\
\hline Engagement & $\begin{array}{l}\text { (engagement OR interaction* OR marketing OR "relationship management" OR collaborat* OR } \\
\text { cooperat* OR co-operat* OR co-creat* OR co-produc* OR "open innovation" OR "user } \\
\text { innovation") }\end{array}$ \\
\hline
\end{tabular}

TABLE 2

Inclusion and exclusion criteria

\begin{tabular}{|c|c|c|}
\hline Criterion & Inclusion & Exclusion \\
\hline $\begin{array}{l}\text { Study } \\
\text { type }\end{array}$ & $\begin{array}{l}\text { Empirical and theoretical/conceptual } \\
\text { studies. Peer reviewed; working /conference } \\
\text { articles included if high quality }\end{array}$ & \\
\hline Language & English & Any other language \\
\hline Sector & $\begin{array}{l}\text { Private sector; can include private sector } \\
\text { firms' engagement with public sector }\end{array}$ & $\begin{array}{l}\text { Any study which does not include consideration of } \\
\text { private sector firms }\end{array}$ \\
\hline Date & 1970 to 2014 & Any study published before 1970 \\
\hline Relevance & $\begin{array}{l}\text { - } \\
\text { - Addresses sustainability innovation and } \\
\text { stakeholder engagement processes } \\
\text { - Level of analysis - firm level practices } \\
\text { and processes } \\
\text { - Innovation consistent with } \\
\text { environmental sustainability (can also } \\
\text { include social and economic } \\
\text { sustainability) }\end{array}$ & $\begin{array}{l}\text { - Not directly relevant to the research question - } \\
\text { e.g. sustainability only in the sense of } \\
\text { continuance; environment not relating to the } \\
\text { natural environment } \\
\text { - Level of analysis - not firm-level practices and } \\
\text { processes (e.g. community initiatives/activities) } \\
\text { - Innovation consistent with social but not } \\
\text { environmental sustainability } \\
\text { - Technical research on manufacturing/supply chain }\end{array}$ \\
\hline
\end{tabular}


TABLE 3

Journals with two or more articles in the review

\begin{tabular}{lr}
\hline Journal title & $\begin{array}{r}\text { No. of } \\
\text { articles }\end{array}$ \\
\hline Journal of Cleaner Production & 17 \\
Business Strategy \& the Environment & 11 \\
Journal of Product Innovation Management & 5 \\
Journal of Business Ethics & 4 \\
MIT Sloan Management Review & 4 \\
Corporate Governance: The International Journal of Business in Society & 3 \\
European Journal of Innovation Management & 3 \\
Industrial Marketing Management & 3 \\
Ecological Economics & 2 \\
Industry \& Innovation & 2 \\
R\&D Management & 2 \\
Research Policy & 2 \\
Technovation & 2 \\
\hline
\end{tabular}

TABLE 4

Article by type of stakeholder

\begin{tabular}{cr}
\hline Stakeholder type & $\begin{array}{r}\text { No. of } \\
\text { articles }\end{array}$ \\
\hline External stakeholders & $\mathbf{6 0}$ \\
Users/Consumers & 9 \\
Suppliers & 9 \\
NGOs/NPOs & 7 \\
Government / regulators & 5 \\
Regional networks & 3 \\
Community & 3 \\
Universities & 2 \\
External - general & 22 \\
Internal stakeholders & $\mathbf{2 8}$ \\
\hline Total articles & $\mathbf{8 8}$ \\
\hline
\end{tabular}


TABLE 5: Review findings relating to external integrative capability

\begin{tabular}{|c|c|c|}
\hline Author & Stakeholder & Finding \\
\hline \multicolumn{3}{|l|}{ Building bridges } \\
\hline $\begin{array}{l}\text { Hansen \& Grosse- } \\
\text { Dunker, } 2009\end{array}$ & General & $\begin{array}{l}\text { The social effects of innovation can be accurately assessed by means of panels of experts, stakeholder dialogues and } \\
\text { stakeholder advisory boards }\end{array}$ \\
\hline Hoffmann, 2007 & Users & $\begin{array}{l}\text { Boundary spanning activities enable organizations to monitor, sense and interact with environmental forces, and to transfer } \\
\text { information across boundaries, and hence play an important part in maintaining organizational viability and adaptability }\end{array}$ \\
\hline Holmes \& Smart, 2009 & NGOs & $\begin{array}{l}\text { There are two types of boundary-spanning roles: 1) formal responsibility from senior management to 'manage' innovation } \\
\text { opportunities 2) a'conduit' to facilitate search and exploration to locate opportunities for innovation through idea exchange }\end{array}$ \\
\hline Holweg, 2014 & Government & $\begin{array}{l}\text { A permanent forum for government-industry exchange can be successfully established; the joint creation of roadmaps } \\
\text { provides a joint statement that helps government guide its policy and firms to reduce uncertainty about future policy }\end{array}$ \\
\hline $\begin{array}{l}\text { Klewitz, Zeyen \& } \\
\text { Hansen, } 2012\end{array}$ & Government & $\begin{array}{l}\text { A proactive approach by a public intermediary is one essential push factor to trigger eco-innovations in SMEs with low } \\
\text { absorptive capacity }\end{array}$ \\
\hline von Malmborg, 2007 & $\begin{array}{l}\text { Regional } \\
\text { networks }\end{array}$ & $\begin{array}{l}\text { Local authorities' role in actor networks related to regional sustainable development are either teacher (they hold knowledge, } \\
\text { information and ideas and transfer it to companies) or tutor (put companies in touch with consultants and technical experts) }\end{array}$ \\
\hline $\begin{array}{l}\text { Murphy \& Arenas, } \\
2011\end{array}$ & Community & $\begin{array}{l}\text { "Collaborations tend to enjoy more success when respected and independent third-party organizations are involved as } \\
\text { facilitators and capacity builders" (p.114) }\end{array}$ \\
\hline Roy \& Whelan, 1992 & Suppliers & $\begin{array}{l}\text { The environmental impact of products can be managed though the creation of an 'issue-based' network. There should be equal } \\
\text { representation of partners with equal financial contribution }\end{array}$ \\
\hline Stafford et al., 2000 & NGOs & $\begin{array}{l}\text { If firms rely on a green NGO acting as a strategic bridge between a firm and its environmental stakeholders, then the timing of } \\
\text { the goal achievement of the two parties is critical }\end{array}$ \\
\hline Triguero et al., 2013 & Universities & Collaborative networks with research institutes, agencies and universities are essential to drive all types of eco-innovation \\
\hline $\begin{array}{l}\text { Urbaniec \& } \\
\text { Gerstlberger, } 2011\end{array}$ & Suppliers & $\begin{array}{l}\text { The authority and reputation of the coordinator influences the successful generation of environmental innovations and their } \\
\text { implementation. The coordinator acts as a "multiplier" of environment-innovative industry solutions }\end{array}$ \\
\hline \multicolumn{3}{|c|}{ Developing engagement processes } \\
\hline Bartlett, 2009 & Community & $\begin{array}{l}\text { Community profiling (e.g. census information, official stats, mapping \& geo-data, interviews and surveys) can "go beyond the } \\
\text { 'surface meaning' of consultation data in order to uncover the 'hidden' wants and needs" (p.413) }\end{array}$ \\
\hline van Bommel, 2011 & Suppliers & Cooperation in supply networks is characterized by trust, reputation, joint programmes and cooperative information systems \\
\hline $\begin{array}{l}\text { Driessen \& Hillebrand, } \\
2013\end{array}$ & General & $\begin{array}{l}\text { Stakeholder issue identification for 'market' stakeholders includes focus groups, store checks, user observation studies. For } \\
\text { 'non-market' stakeholders: monitoring of regulation, dialogue with special interest groups (SIGs), SIGs as advisors }\end{array}$ \\
\hline $\begin{array}{l}\text { Heiskanen \& Lovio, } \\
2010\end{array}$ & Users & $\begin{array}{l}\text { User involvement can help to enhance the acceptance of low-energy solutions. The project could have been improved had } \\
\text { users been involved more intensively, and use been made of user participation in communication about the project }\end{array}$ \\
\hline Hoffmann, 2007 & Users & $\begin{array}{l}\text { Success factors for consumer contribution to sustainable product development include: an open company attitude, senior } \\
\text { management support, clearly defined roles and tasks, creative techniques, small working groups, direct communications, } \\
\text { non-hierarchical dialogue and flexible moderation }\end{array}$ \\
\hline
\end{tabular}




\begin{tabular}{|c|c|c|}
\hline \multicolumn{3}{|c|}{ Develping engagement processes (cont.) } \\
\hline Jamali et al., 2011 & General & $\begin{array}{l}\text { The more innovative partnerships reported different patterns of engagement: regular interactions, open lines of } \\
\text { communication; nurturing over time a strong cooperative competence building on trust, communication and good } \\
\text { coordination }\end{array}$ \\
\hline $\begin{array}{l}\text { Kourula \& Halme, } \\
2008\end{array}$ & NGOs & $\begin{array}{l}\text { Different CR types involve different forms of cooperation: Philanthropy: sponsorship, employee volunteering; CR integration: } \\
\text { dialogue, common programs, partnerships, consultation, research collaboration; CR innovation: common programs, } \\
\text { partnerships }\end{array}$ \\
\hline Liao et al., 2013 & Users & $\begin{array}{l}\text { Innovative methods are needed to encourage consumer participation in designing sustainable products that satisfy their needs, } \\
\text { since methods to identify product eco-design issues (e.g. life-cycle analysis) mainly focus on environmental aspects not } \\
\text { customer needs }\end{array}$ \\
\hline Mathur et al., 2008 & General & $\begin{array}{l}\text { Key requirements for collaborative process: arenas accessible to all those with a stake; transferring power to make decisions } \\
\text { close to those stakeholders who will be affected by them; engagement methods which allow diverse points of view to be } \\
\text { explored }\end{array}$ \\
\hline $\begin{array}{l}\text { McDonald \& Young, } \\
2012\end{array}$ & NGOs & $\begin{array}{l}\text { Leadership effectiveness, communication and trust are success factors for cross-sector collaboration. Supporting factors are: } \\
\text { government support, employee support, interaction or engagement opportunities and evaluation when planning and } \\
\text { monitoring }\end{array}$ \\
\hline Senge et al., 2007 & General & $\begin{array}{l}\text { Successful collaboration efforts embrace three interconnected types of work - conceptual, relational and action-driven, which } \\
\text { form a learning ecology for systematic change. Relational work: Reflective conversation and working with mental models }\end{array}$ \\
\hline Slotegraaf, 2012 & Users/ suppliers & $\begin{array}{l}\text { Businesses are developing strategies for using technology and networks to leverage input from consumers and suppliers in } \\
\text { seeking ideas and developing new products }\end{array}$ \\
\hline $\begin{array}{l}\text { Spena \& De Chiara, } \\
2012\end{array}$ & Suppliers & $\begin{array}{l}\text { A more collaborative approach with suppliers fosters creativity and innovation (through inclusivity and diversity). Specific } \\
\text { mechanisms and processes are identified }\end{array}$ \\
\hline $\begin{array}{l}\text { Verghese \& Lewis, } \\
2007\end{array}$ & Suppliers & $\begin{array}{l}\text { Environmental innovation in industrial packaging requires: an effective project champion; senior management/CEO support; } \\
\text { communication and engagement with partners; an open mind; the identification of multiple benefits }\end{array}$ \\
\hline \multicolumn{3}{|l|}{ Achieving alignment } \\
\hline van Bommel, 2011 & Suppliers & $\begin{array}{l}\text { Cooperation in supply networks is characterized by: 1) trust 2) reputation 3) joint programmes 4) cooperative information } \\
\text { systems }\end{array}$ \\
\hline Lee \& Kim, 2011 & Suppliers & $\begin{array}{l}\text { Two important factors for green innovations are coordination and alignment of project teams (e.g. monitoring and evaluation, } \\
\text { learning from each other, sharing experiences and information), and effective communication with suppliers }\end{array}$ \\
\hline $\begin{array}{l}\text { Murphy \&Arenas, } \\
2011\end{array}$ & Community & $\begin{array}{l}\text { "The closer the collaborations fit with the missions, values, and strategies of each partner, the more likely the relationship will } \\
\text { be to create value" (p.109). They tend to allocate more resources and have fewer incompatibilities in their relationship }\end{array}$ \\
\hline $\begin{array}{l}\text { McDonald \& Young, } \\
2012\end{array}$ & NGOs & $\begin{array}{l}\text { "Cross-sector relationships can progress along a collaboration continuum so long as partners reassess their needs and } \\
\text { expectations and choose to continue to innovate" (p.65) }\end{array}$ \\
\hline Senge et al., 2007 & General & $\begin{array}{l}\text { Radical methods needed for complex change processes and large scale dialogue. Systems thinking, working with mental } \\
\text { models, fostering personal and shared vision (p.45) }\end{array}$ \\
\hline $\begin{array}{l}\text { Verghese \& Lewis, } \\
2007\end{array}$ & Suppliers & $\begin{array}{l}\text { Environmental innovation in industrial packaging requires: alignment of environmental objectives with business strategies; } \\
\text { involvement of important stakeholders at beginning of project; clear and shared objectives for functional requirements and } \\
\text { redesigning objectives }\end{array}$ \\
\hline
\end{tabular}


Engaging employees

Bocken et al., 2014

Teams should be multidisciplinary, and creativity and environmental knowledge are essential. Eco-innovation is a "collective endeavour" (p.52)
between top management and R\&D (highest involvement), marketing, sales, engineers and designers

Bos-Brouwers, The time and support employees receive to elaborate on innovative ideas, combined with the effort and ambitions of the owner/manager are important

2010

Kiron, 2012

Kiron et al., 2013

Kruschwitz \&

Pflueger, 2012

Strong support from Chairman \& CEO, global strategic leadership team, four business units and an external sustainability advisory board have been crucial to building and meeting aggressive sustainability metrics [Kimberley-Clarke]

The factors associated with getting economic value from sustainability activities include top management support

"Reporting into marketing gives us better understanding of the connections between sustainability-related issues and brand value and brand equity. We have better access to tools and more access to information that help us understand what we can do that our customers need, as well as connections into the analyst and stakeholder community" (p.4) [Dell]

\section{Lenox \&}

Ehrenfeld, 1997

McDonald \&

Young, 2012

Communicative linkages e.g. Incorporate sustainability directly into product development (integrated product development teams)

\section{Using environmental data}

\section{Dangelico \&}

Pujari, 2010

Gmelin \& Seuring,

2014

Guiltinan, 2009

Hallstedt et al.,

2010

Horbach, 2008

Könnölä \& Unruh, 2007

de Kraker et al.,

2013

Lenox \&

Ehrenfeld, 1997

Pujari et al., 2004
Leadership effectiveness, communication and trust were verified as success factors for cross-sector collaboration. Variables which support evolution include employee support

\section{A key challenge to integrating environmental sustainability is management of information flows and coordination of resources within and outside of the product development team}

Successful collaboration is dependent on technology and organized processes. Tools, inter-operability standards, architectures etc. have to be coordinated so that barriers do not prevent collaboration

"Many new processes and technologies have been developed for the cross-functional communication process in firms where sustainable new product development is a priority" (e.g. "design for environment," "life cycle assessment) (p.24)

The key ways to improve sustainability integration between senior management and product development include a standardized toolbox for sustainability-related information in decision processes

Environmental management tools are important for the introduction of environmental product innovations

While environmental management systems (EMS) may initially produce improvements in environmental performance, EMS may also constrain organizations' focus to the exploitation of present production systems rather than exploring for superior discontinuous innovations

Social network software platforms did support users in their network interactions, particularly keeping other users informed, sharing experiences and information and collaborating on joint document

Communicative linkages e.g. training in environmental design to designers; technical systems (databases, design aides; use of gatekeepers)

"Cross functional integration enhances the diffusion of market and customer knowledge among all members of a project team, not just during development, but also at later stages of test marketing and commercialisation" (p.383) 


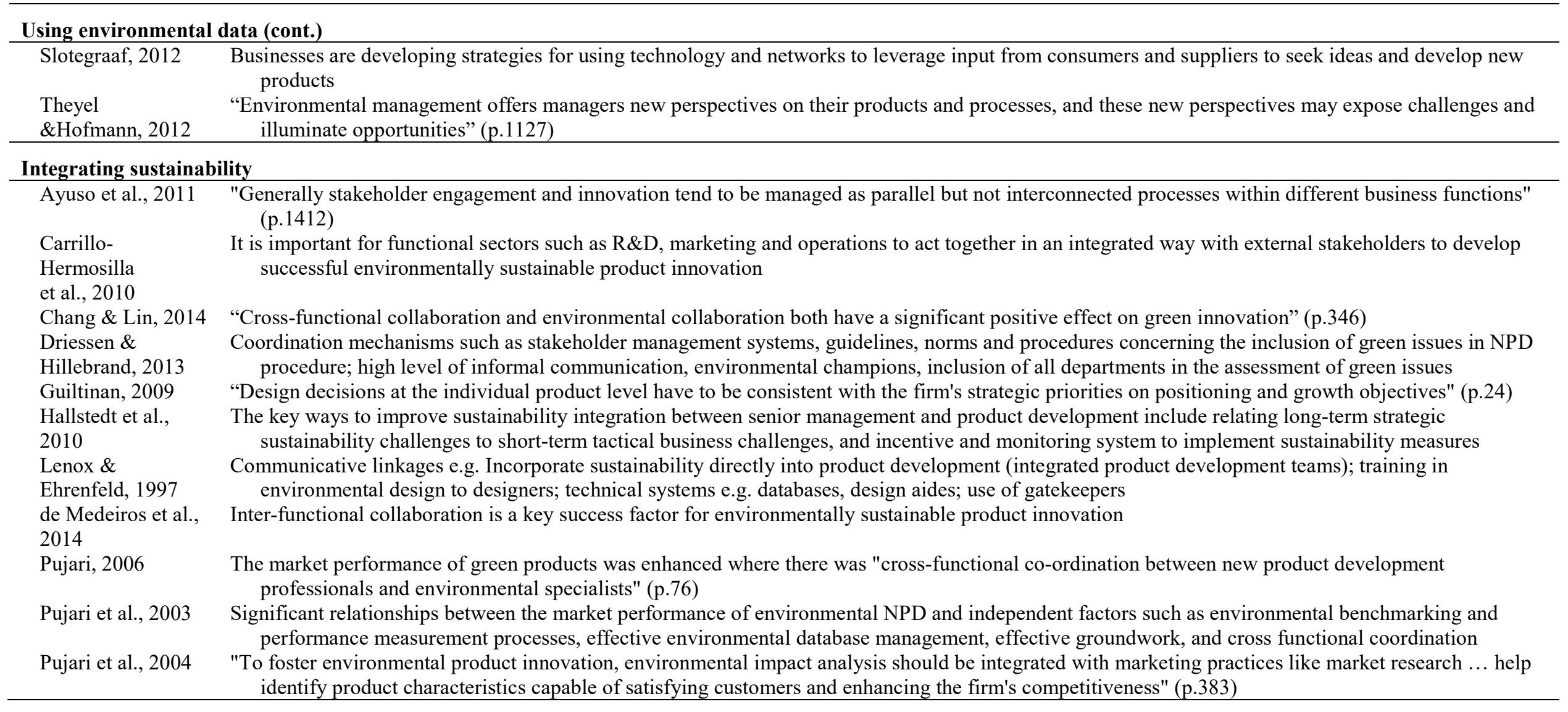


TABLE 7: Review findings related to value framing capability

\section{Author}

\section{Finding}

Thinking systemically

De-Burgos-Jiménez et al., 2011

Foxon \& Pearson,

2008

Guiltinan, 2009

Holweg, 2014

Lenox \& Ehrenfeld, 1997

Pujari et al., 2003

Senge et al., 2007
"If the capacities of both companies and communities are strong, the conditions exist for a society with full integration of community stakeholders within a firm, and with the firm acting as just another stakeholder for solving complex social problems" (p.1382)

"Shared visions and strategic goals for long-term technological and institutional changes ned to be developed by public and private actors working together" (p.S159

More sustainable design practices can be developed but cultural changes at the product design level are likely to be somewhat constrained by corporate and marketing realities and perceptions

The forum required firms to shift their attention away from individual company needs and toward the collective needs faced by all industry players; from specific firm-level subsidies to the strengthening of the UK automotive industry as a whole

"Traditionally, environmental issues have been buffered from the design and manufacturing functions. Consequently, attitudes develop which treat environmental issues as not being of concern" "The challenge to firms is to break down the 'thought worlds' of functional groups and to create enough mutual understanding to effectively communicate information" (p.191)

"Responding to sustainability challenges in industrial NPD is more likely to be hampered by organizational barriers than technical/process barriers" (p.389)

Commercial interests and proprietary know-how must be balanced with public interest when tackling systemic issues. This means "focusing on issues that are larger than individual organizations and improving the related systems that can benefit all" (p.52)

\section{Empathizing}

Aschehoug et al., 2012 There is a substantial gap between environmental information available and what the firm knows due to culturing framing and filtering mechanisms

Delmas \& Toffel, 2004 "Pressure is managed according to the cultural frame of the unit that receives it" (p.215). The way in which managers perceive and act on stakeholder pressure depends on company-specific factors

Hoffmann, 2007

Holmes \& Smart, 2009

Klewitz and Hansen,

2014

Consumers had significantly more learning success [from contributing to sustainable product development] than the company, whose moderate learning results are explained through filtering mechanisms that constrained the company to certain information

Murphy \& Arenas,

2011

Senge et al., 2007

Cross-sector partners are "driven by very different concerns and operate according to different sets of values and cultures" (p.395)

The sustainability-oriented innovation process can be remodelled by "increasing the reflexivity of the process through the interaction with externa actors from the SME's value chain" (p.67)

Principles for cross-cultural bridge building include: Respected individuals as representatives, strong communication skills and culturally literate, empathetic, open-minded boundary spanners

Successful collaboration efforts embrace three interconnected types of work - conceptual, relational and action-driven, which form a learning ecology for systematic change. Relational work: Reflective conversation and working with mental models 
JPIM \#09-15-1270.Accepted

\section{Hybridizing}

Le Ber \& Branzei,

2010

Bönte \& Dienes, 2013

Driessen \& Hillebrand

2013

Mathur et al., 2008

Poncelet, 2001

Sol et al., 2013
Partners initially contrast their sector-embedded diagnostic frames (divergent understanding of the problem) and then work together to deliberately develop partnership-specific prognostic frames (understanding of possible solutions)

There is a "not invented here" syndrome (Katz and Allen 1982) associated with external partnerships

"Acknowledging tension between stakeholder issues is the first step toward reaching consensus within the team" (p.372). Creating a culture where green issues are regularly discussed in new product development meetings

A democratic approach values the process of participation for the ethical issues of equity and empowerment of citizens. The desire to engage with stakeholders in project decision-making processes is also linked to enhancing the sense of ownership of a project

"Conflicting interests, values, and world views with which these actors approach current natural resources and environmental quality issues" (p. 13)

"Creating pathways to sustainability does not occur through the mere combination of existing knowledge, but requires on-going interaction between multiple actors willing and able to lay their own values and interests on the table" (p.35) 
TABLE 8: Review findings related to systemized learning capability

\begin{tabular}{|c|c|}
\hline Author & Finding \\
\hline $\begin{array}{l}\text { Ayuso et al., } \\
2006\end{array}$ & $\begin{array}{l}\text { Dynamic capabilities for generating sustainability innovations in accordance with stakeholder needs identified as stakeholder dialogue and stakeholder } \\
\text { knowledge integration }\end{array}$ \\
\hline $\begin{array}{l}\text { Ayuso et al } \\
2006\end{array}$ & $\begin{array}{l}\text { Companies' structures and systems to foster innovation illustrate features important for integrating stakeholder knowledge: 1) non-hierarchical structures } \\
\text { that favour direct communication and proximity between people 2) flexible structures and systems that facilitate the development of new ideas }\end{array}$ \\
\hline $\begin{array}{l}\text { Ayuso et al., } \\
2011\end{array}$ & $\begin{array}{l}\text { Knowledge management capability, together with internal and external stakeholder engagement capabilities has a positive effect on the sustainable } \\
\text { innovation orientation of the firm. However, more research is needed intothe relationship and interaction between these three capabilities }\end{array}$ \\
\hline $\begin{array}{l}\text { Blum-Kusterer \& } \\
\text { Hussain, } 2001\end{array}$ & $\begin{array}{l}\text { The co-evolutionary (learning) approach to innovation (i.e. firm's norms, routines and past experiences are influential) versus the neo-classical (i.e. firms } \\
\text { only respond to profit signals) better captures the complexity of the corporate eco-change process }\end{array}$ \\
\hline $\begin{array}{l}\text { Chang \& Lin, } \\
2014\end{array}$ & $\begin{array}{l}\text { Cross-functional collaboration reduces the gap between the amount of green information possessed by a firm and that which is understood by the firm. } \\
\text { However, in the process of environmental collaboration, a high level of external green knowledge improves performance of green innovation, whereas a } \\
\text { high level of internal green knowledge-sharing can reinforce existing expertise and operational routines, which may lead to inertia }\end{array}$ \\
\hline $\begin{array}{l}\text { De Marchi et al., } \\
2013\end{array}$ & $\begin{array}{l}\text { Firms for which green innovation is strategic have different knowledge strategies as compared with those for whom it is tactical or are non-green } \\
\text { innovators. These firms have higher R\&D intensity and carry out more training as well as interacting with more and more diverse external stakeholders }\end{array}$ \\
\hline $\begin{array}{l}\text { Driessen \& } \\
\text { Hillebrand, } 2013\end{array}$ & Organizations learn to integrate multiple stakeholder issues over time by accumulating experiences. It is difficult to build overnight or copy from others \\
\hline Horbach, 2008 & e introduction of new or relevant changes of organizational structures are especially important for environmental innovations \\
\hline $\begin{array}{l}\text { Klewitz \& } \\
\text { Hansen, } 2014\end{array}$ & $\begin{array}{l}\text { Interaction (with stakeholders) for sustainability-oriented innovation is an enabling mechanism which leads to learning and innovative capacity-building } \\
\text { in SMEs that ultimately translates into innovation at the product, process and organizational level }\end{array}$ \\
\hline $\begin{array}{l}\text { Laperche \& } \\
\text { Uzunidis, } 2012\end{array}$ & $\begin{array}{l}\text { Firms have initiated a process of reorganization or restructuring of their knowledge capital. Collaborative research has become an essential component in } \\
\text { building knowledge capital in industrial corporations }\end{array}$ \\
\hline Sharma \& & Firms with proactive environmental strategies developed a capability for higher-order learning, and a capability for continuous improvement. "Companies \\
\hline $\begin{array}{l}\text { Vrendenburg, } \\
1998\end{array}$ & $\begin{array}{l}\text { provided an organizational context to support experimentation and the seeking of opportunities at the business/natural environment interface in an } \\
\text { efficient and effective manner through employee compensation systems and by facilitating management discretion" (p.742) }\end{array}$ \\
\hline Sol et al., 2013 & $\begin{array}{l}\text { "Social learning as a dynamic process in which trust, commitment and reframing are continuously produced and reproduced through the (inter)actions of } \\
\text { individual actors (p.35) }\end{array}$ \\
\hline $\begin{array}{l}\text { Quist \& Tukker, } \\
2013\end{array}$ & $\begin{array}{l}\text { There are three types of innovation positioned on two axes of: 1) Who learns: Small groups of niche actors to actors making up societal systems and } 2 \text { ) } \\
\text { What type of learning: } 1 \text { st order (incremental) to } 2 \text { nd order (radical). Innovation types are: } 1 \text { ) Niche / local experiments } 2 \text { ) Optimization /redesign and } \\
\text { 3) System innovation. Calls for more research into how } 2^{\text {nd }} \text { order learning can be fostered in small-scale setting to stimulate similar learning in wider } \\
\text { settings }\end{array}$ \\
\hline
\end{tabular}


TABLE 9: Review findings related to marketing capability

\begin{tabular}{l} 
Author \\
\hline Anttonen et al \\
2013 \\
Aschehoug, B \\
and Støren, 2012 \\
Mariadoss, \\
Tansuhaj and \\
Mouri, 2011 \\
Polonsky and \\
Ottman, 1998
\end{tabular}

\section{Finding}

Marketing efforts for advance materials efficiency services are directed to environment / health \& safety professionals who cannot make purchasing decisions. The offer is not specific enough, or presented in terms of cost savings / other benefits

"Sales and management may unintentionally filter out or miss the opportunity of environmental information (EI), as they are likely to be mostly occupied with sales numbers, pricing and delivery" (p. 4)

Marketing capabilities that support technical ((T) new product) and non-technical ((NT) (programme) sustainable innovation are: Product packaging (T); sales ( $\mathrm{T} \& \mathrm{NT}$ ); product development (T); channel linking ( $\&$ NT) (i.e. good networks with upstream and downstream channel members); price setting (NT); relationship building (NT) (with other constituents)

The intricacies of environmental issues require that marketers involve a broad set of stakeholders in the green new product development process (p. 533). Marketers failed to include stakeholders with environmental expertise

"Firms believe they must interact with customers in order to be able to educate them or change their expectations of organizational behaviour. Marketers are not simply reacting to their stakeholders' interests or constraints, but are proactive in modifying firm behaviour and working with their stakeholder to obtain the desired outcome" (p.550)

"It appears that marketers are working within the constraints within the business environment i.e. using what Polonsky (1996) called an adopting strategy. It is therefore unclear if firms are designing the "best" green products or truly addressing all their stakeholder interests" (p.551)

Pujari, Peattie $\quad$ "Clear project definition, good market analysis, marketing research, and sales forecasting to gain a clear understanding of users' needs and wants are all and Wright, 2004

crucial for successful new products. Proficient up-front activities for environmentally responsive industrial products are as essential as in conventional new product development processes" (p.382)

\section{TABLE 10: Review findings related to environmental capability}

\begin{tabular}{|c|c|}
\hline Author & Finding \\
\hline $\begin{array}{l}\text { Dangelico \& } \\
\text { Pujari, } 2010\end{array}$ & Environmental know-how, clean technology/manufacturing processes, building knowledge on measuring environmental performance of products \\
\hline Kammerer, 2009 & $\begin{array}{l}\text { Green capabilities: Use of products' environmental attributes in marketing }(45 \%) \text {; voluntary environmental targets for products }(42 \%) \text {; systematic } \\
\text { environmental analysis of products }(25 \%) \text {; environmental training for product managers }(21 \%) \text {; environmental management system }(18 \%)\end{array}$ \\
\hline Pujari, 2006 & $\begin{array}{l}\text { Factors that influence market performance of greener products are cross-functional coordination between new product development professionals and } \\
\text { environmental specialists, supplier involvement, market focus and life-cycle analysis }\end{array}$ \\
\hline Pujari et al., 2003 & $\begin{array}{l}\text { Statistically significant relationships between market performance of ENPD and independent factors such as environmental benchmarking and } \\
\text { performance measurement processes, effective environmental database management, effective groundwork, and cross functional coordination }\end{array}$ \\
\hline $\begin{array}{l}\text { Theyel and } \\
\text { Hofmann, } 2012\end{array}$ & $\begin{array}{l}\text { "Environmental management offers managers new perspectives on their products and processes, and these new perspectives may expose challenges and } \\
\text { illuminate opportunities" (p.1127) }\end{array}$ \\
\hline
\end{tabular}


TABLE 11: Review findings related to benefits of stakeholder engagement in environmental innovation

\section{Benefit}

Environmental performance

Financial performance

Competitive advantage

Reputation

Risk management

\section{Legitimacy}

Employee brand

\section{Finding and author}

Environmental impact reduction (Oxborrow and Brindley, 2013); eco-efficiency (Kourula and Halme, 2008, p. 565); reducing environmental impacts of supply chain (Albino et al., 2012); efficient use of raw materials, energy and other resources (Liao, Lou and Gao, 2013; De Marchi and Grandinetti 2013); optimized consumption thorough use of renewable and recycled materials (Liao et al., 2013; De Marchi and Grandinetti, 2013)

Financial performance (Dangelico et al., 2013; Young et al., 2010); market opportunities (Dangelico et al., 2013; Oxborrow and Brindley, 2013); access to new market segments (Gonzalez-Padron and Nason, 2009); increased revenues (Carrillo-Hermosilla et al., 2010); increased demand for products and services (Gonzalez-Padron and Nason, 2009); increased market share (Roy and Whelan, 1992); efficient processes (Lee and Kim, 2011); cost savings (Carrillo-Hermosilla et al., 2010; Gonzalez-Padron and Nason, 2009; Liao et al., 2013; Oxborrow and Brindley, 2013); pooling resources (Yarahmadi and Higgins, 2012); profitability (Kiron et al., 2013)

Market opportunities (Oxborrow and Brindley, 2013); new business models (Klewitz and Hansen, 2014; Kourula and Halme, 2008; Murphy and Arenas, 2011); new markets (Kourula and Halme, 2008); new commercially viable products (Aschehoug et al., 2012); innovative services (Bartlett, 2009); development of innovative capabilities (Bartlett, 2009); enhanced creativity (Lee and Kim, 2011); access to knowledge and expertise (Lee and Kim, 2011; Murphy and Arenas, 2011); new technological resources (Murphy and Arenas, 2011); improved management of disruptive change (Murphy and Arenas, 2011); faster adoption / customer acceptance of innovation (Nakata and Weidner, 2012)

Reputation (Kourula and Halme, 2008; Murphy and Arenas, 2011); brand value (Kourula and Halme, 2008); brand recognition (Murphy and Arenas, 2011); customer satisfaction (Luo and Bhattacharya, 2009, p.15); trust, improved image and compliance with future legislation (Anttonen et al., 2013); attracting new customers (Carrillo-Hermosilla et al., 2010); understanding and fulfilling customer needs (Liao et al., 2013); consumer patronage (Murphy and Arenas, 2011)

Reliable supply of high quality material for production (Gonzalez-Padron and Nason, 2009); better control over suppliers (Klewitz and Hansen, 2014) reduced uncertainty of future policy (Holweg, 2014); reduce reputational risk (McDonald and Young, 2012); reduce risk of negative publicity (McDonald and Young, 2012); management of uncertainty (McDonald and Young, 2012); risk sharing (Hansen and Grosse-Dunker, 2009; Roy and Whelan, 1992; Yarahmadi and Higgins, 2012)

Compliance with environmental laws and regulation (Yarahmadi and Higgins, 2012); lowering of future regulation (Gonzalez-Padron and Nason, 2009); development of industry standards (Roy and Whelan, 1992)

Employee morale and retention (Murphy and Arenas, 2011) 


\section{FIGURE 1}

A hierarchical capability-based framework for stakeholder engagement in environmental innovation

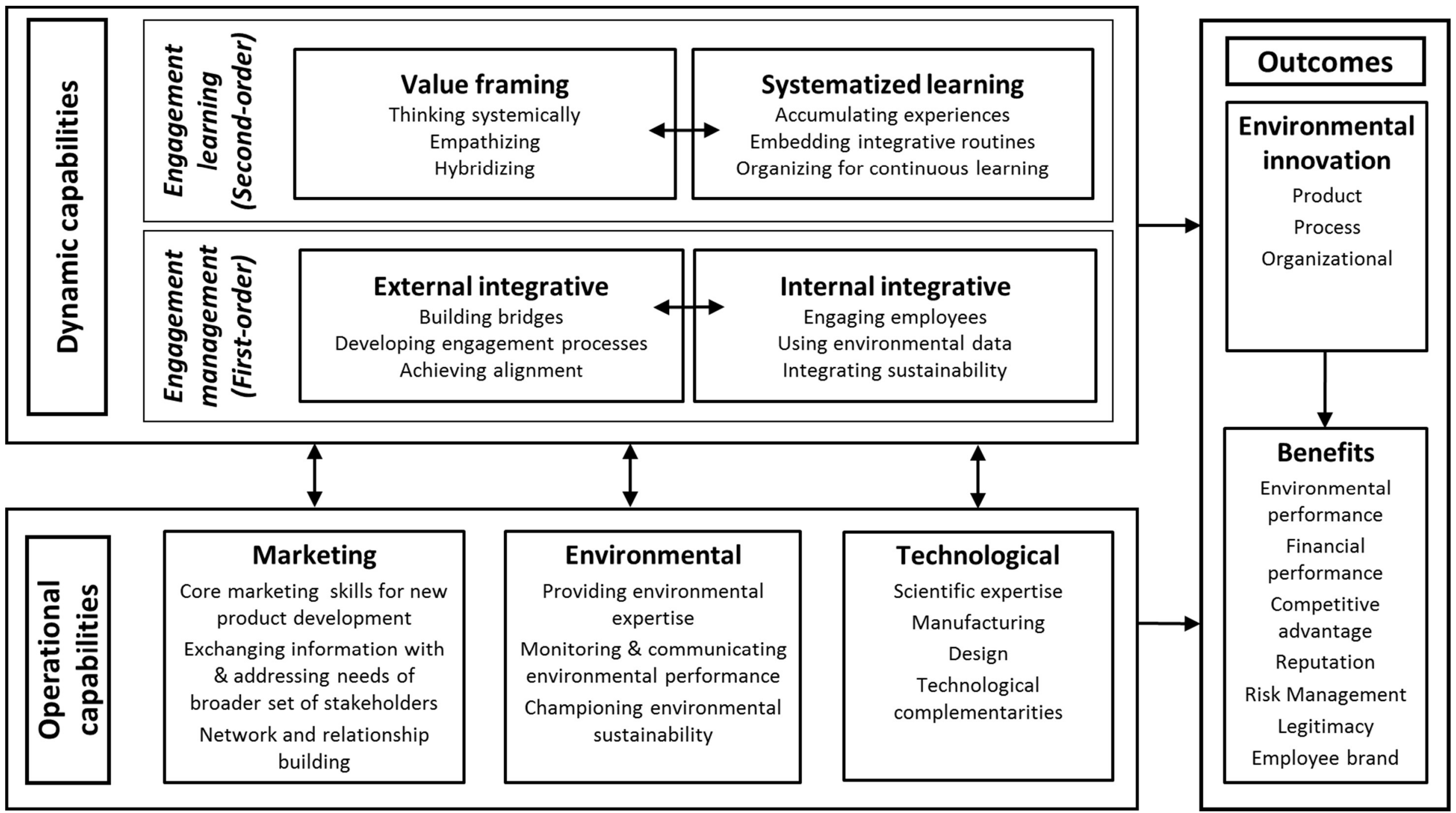




\section{Appendix 1: Quality assessment criteria for review articles}

\begin{tabular}{|c|c|c|c|c|c|}
\hline \multirow[t]{2}{*}{ Element } & \multicolumn{5}{|l|}{ Level } \\
\hline & 0 Absence & 1 Low & 2 Medium & 3 High & Not applicable \\
\hline 1.Theory robustness & $\begin{array}{l}\text { The article does not } \\
\text { provide enough } \\
\text { information to } \\
\text { assess this criterion }\end{array}$ & $\begin{array}{l}\text { Poor awareness of } \\
\text { existing literature and } \\
\text { debates. Under- or over- } \\
\text { referenced. Low validity } \\
\text { of theory }\end{array}$ & $\begin{array}{l}\text { Basic understanding of the } \\
\text { issues around the topic being } \\
\text { discussed. The theory is } \\
\text { weakly related to data }\end{array}$ & $\begin{array}{l}\text { Deep and broad knowledge } \\
\text { of relevant literature and } \\
\text { theory relevant for } \\
\text { addressing the research. } \\
\text { Good relations theory-data }\end{array}$ & $\begin{array}{l}\text { This element is } \\
\text { not applicable to } \\
\text { the document or } \\
\text { study }\end{array}$ \\
\hline $\begin{array}{l}\text { 2.Methodology, data } \\
\text { and supporting } \\
\text { arguments }\end{array}$ & As above & $\begin{array}{l}\text { Data inaccuracy and not } \\
\text { related to theory. } \\
\text { Flawed research design }\end{array}$ & $\begin{array}{l}\text { Data are related to } \\
\text { arguments, though there are } \\
\text { some gaps. Research design } \\
\text { may be improved }\end{array}$ & $\begin{array}{l}\text { Data strongly supports } \\
\text { arguments. Besides, the } \\
\text { research design is robust: } \\
\text { sampling, data gathering, } \\
\text { data analysis is rigorous }\end{array}$ & As above \\
\hline $\begin{array}{l}\text { 3. Implication for } \\
\text { practice }\end{array}$ & As above & $\begin{array}{l}\text { Very difficult to } \\
\text { implement the concepts } \\
\text { and ideas presented. Not } \\
\text { relevant for practitioners } \\
\text { or professionals }\end{array}$ & $\begin{array}{l}\text { There is potential for } \\
\text { implementing the proposed } \\
\text { ideas, with minor revisions } \\
\text { or adjustments }\end{array}$ & $\begin{array}{l}\text { Significant benefit may be } \\
\text { obtained if the ideas being } \\
\text { discussed are put into } \\
\text { practice }\end{array}$ & As above \\
\hline 4.Generalizability & As above & $\begin{array}{l}\text { Only to the population } \\
\text { studied }\end{array}$ & $\begin{array}{l}\text { Generalizable to } \\
\text { organizations of similar } \\
\text { characteristics }\end{array}$ & High level of generalizability & As above \\
\hline $\begin{array}{l}\text { 5. Contribution plus } \\
\text { a short statement } \\
\text { summarizing the } \\
\text { article's contribution }\end{array}$ & As above & $\begin{array}{l}\text { Does not make an } \\
\text { important contribution. } \\
\text { It is not clear the } \\
\text { advances it makes }\end{array}$ & $\begin{array}{l}\text { Although using others' ideas, } \\
\text { builds upon the existing } \\
\text { theory }\end{array}$ & $\begin{array}{l}\text { Further develops existing } \\
\text { knowledge, expanding the } \\
\text { way the issue was explained } \\
\text { so far }\end{array}$ & As above \\
\hline
\end{tabular}

Source: Pittaway et al. (2004) 
JPIM \#09-15-1270.Accepted

i also referred to in the dynamic capability literature as operating routines (Zollo and Winter, 2002) zero-order capabilities (Winter, 2003) or functional capabilities (Collis, 1994; Verona, 1999) 